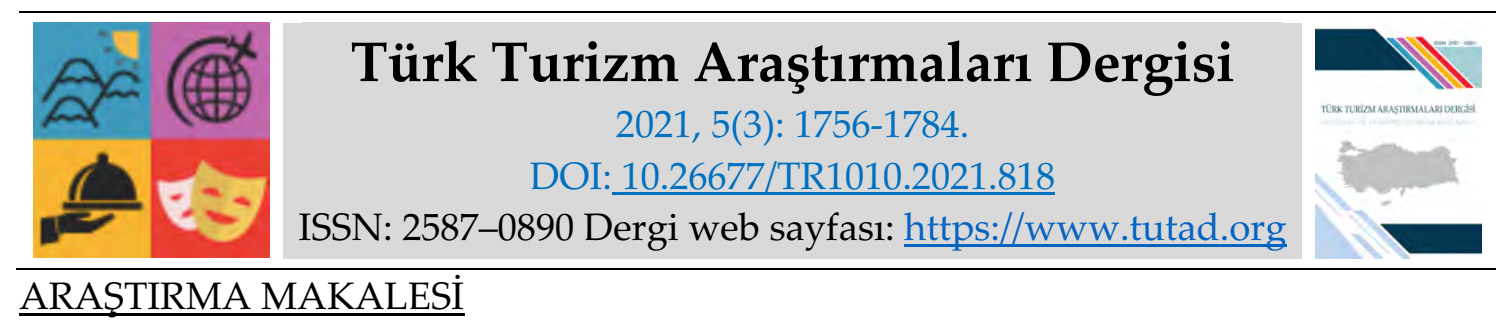

\title{
Dijital Pazarlama Yöneticilerinin Bakış Açısıyla En Uygun Otel Seçimi: Analitik Hiyerarşi Prosesi (AHP) ve PROMETHEE Yaklaşımı
}

Prof. Dr. Mete SEZGİN, Selçuk Üniversitesi, Turizm Fakültesi, Konya, e-posta: metesezgin@selcuk.edu.tr ORCID: https://orcid.org/0000-0001-9079-2520

Öğr. Gör. Murat YURTLU, İskenderun Teknik Üniversitesi, Turizm Fakültesi, Hatay, e-posta: murat.yurtlu@iste.edu.tr ORCID: https://orcid.org/0000-0002-0947-8401

\section{Öz}

İnternetin yaygınlaşması turizmde e-ticaretin hızlı bir biçimde gelişmesini sağlamıştır. Turistlerin tatil kararlarını vermede çeşitli fırsatlar sunarak önemli hale gelen çevrimiçi deneyim paylaşım platformları dünyada en çok ziyaret edilen internet siteleri arasına girmişlerdir. Bunun yanında çevrimiçi seyahat acenteleri internet sitelerinden gerçekleşen rezervasyonlara ilişkin misafir deneyimlerini paylaşarak rezervasyon aşamasında potansiyel misafirlerine tatil kararı sürecinde fırsatlar sunmaktadırlar. Turistlerin deneyimlerine yönelik paylaştıkları olumlu ve olumsuz görüşleri hem deneyim paylaşım platformlarında hem de çevrimiçi seyahat acentelerinde belirli sıralama listelerinin oluşmasını sağlamaktadır. Potansiyel misafirler tatil kararlarını verdikleri süreçte en çok ziyaretçi ve rezervasyon trafiğini ilgili sıralama listelerinde üst sıralarda yer alan işletmelerde oluşturmaktadırlar. Bu araştırmada turistlerin otel tercihinde karar problemine çok kriterli karar verme yöntemlerinden yararlanılarak yanıt vermek amaçlanmıştır. Bunun için Booking.com internet sitesinde İstanbul otelleri listesinde en üst sıralarda yer alan tesislerden ilk yedi alternatif otelin belirlenen yedi kriter üzerinden AHP (Analitik Hiyerarşi Prosesi) yöntemiyle kriter ağırlık değerleri hesaplanmış ve PROMETHEE yöntemiyle de tercih sıralamaları \%89 ölçüm kalitesiyle çok iyi bir karar düzeyinde belirlenmiştir. Araştırmada belirlenen kriterlerden uzman görüşü neticesinde ağırlık değeri en yüksek kriterin "Temizlik" kriteri olduğu tespit edilmiştir. Belirlenen yedi alternatif içerisinden ise Otel 5 alternatifinin en uygun tercih olduğu saptanmıştır. Araştırmada elde edilen bilgiler ışığında analiz edilen alternatif otellerin sıralamalarına ilişkin farklılıkların ortaya çımasının nedeni olarak Booking.com çevrimiçi seyahat acentesinin otel sıralamalarında uyguladığı dinamik faktörlerden kaynaklandığı sonucuna ulaşılmıştır.

Anahtar Kelimeler: Booking.com, Çevrimiçi Pazarlama, Otel Sıralamaları, AHS (Analitik Hiyerarşi Süreci), Çok Kriterli Karar Verme Teknikleri, GAIA Düzlemi.

Makale Gönderme Tarihi: 05.04.2021

Makale Kabul Tarihi: 01.09.2021

Önerilen Atıf:

Sezgin, M. ve Yurtlu, M. (2021). Dijital Pazarlama Yöneticilerinin Bakış Açısıyla En Uygun Otel Seçimi: Analitik Hiyerarşi Prosesi (AHP) ve PROMETHEE Yaklaşımı, Türk Turizm Araştırmaları Dergisi, 5(3): 17561784 .

(c) 2021 Türk Turizm Araştırmaları Dergisi. 


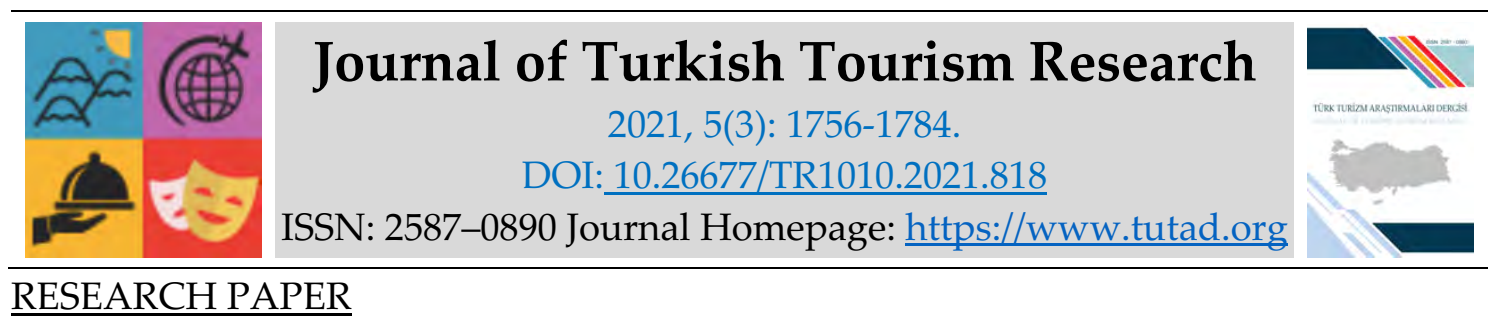

\title{
Selecting the Optimum Hotel from the Perspective of Digital Marketing Managers: Analytical Hierarchy Process (AHP) and PROMETHEE Approach
}

Prof. Dr. Mete SEZGIN, Selçuk University, Faculty of Tourism, Konya, e-mail: metesezgin@selcuk.edu.tr

ORCID: https://orcid.org/0000-0001-9079-2520

Lecturer Murat YURTLU, İskenderun Technical University, Faculty of Tourism, Hatay, e-mail: murat.yurtlu@iste.edu.tr

ORCID: https://orcid.org/0000-0002-0947-8401

\begin{abstract}
The widespread use of the Internet has enabled the rapid development of e-commerce in tourism. Online experience sharing platforms, which have become important by providing various opportunities for tourists to make their holiday decisions, have become one of the most visited websites in the world. In addition, online travel agencies offer opportunities to their potential guests during the holiday decision process by sharing their guest experiences regarding reservations made on their websites. The positive and negative opinions of the tourists about their experiences enable certain ranking lists to be formed in both experience sharing platforms and online travel agencies. During the process of making their holiday decisions, potential guests create the highest visitor and booking traffic in businesses that rank high in the relevant ranking lists. In this study, it is aimed to answer the decision problem of tourists in choosing a hotel by using multi-criteria decision-making methods. For this, criteria weight values were calculated using AHP (Analytical Hierarchy Process) method over seven criteria determined for the first seven alternative hotels among the top-ranked hotels in the list of Istanbul hotels on the Booking.com website and with the PROMETHEE method, the order of preference was determined at a very good decision level with $89 \%$ measurement quality. As a result of the expert opinion among the criteria determined in the research, it was determined that the criterion with the highest weight value was the "cleaning" criterion. Among the seven alternatives determined, Hotel 5 was determined to be the most suitable choice. In the light of the information obtained in the study, it was concluded that the reason for the emergence of the differences regarding the rankings of alternative hotels was due to the dynamic factors applied by Booking.com online travel agency in hotel rankings.
\end{abstract}

Keywords: Booking.com, Online Marketing, Hotel Rankings, AHP (Analytical Hierarchy Process), Multi Criteria Decision Making Techniques, GAIA Plane.

Received: 05.04.2021

Accepted: 01.09.2021

Suggested Citation:

Sezgin, M. and Yurtlu, M. (2021). Selecting the Optimum Hotel from the Perspective of Digital Marketing Managers: Analytical Hierarchy Process (AHP) and PROMETHEE Approach, Journal of Turkish Tourism Research, 5(3): 1756-1784.

(C) 2021 Türk Turizm Araştırmaları Dergisi. 


\section{Gíriş}

Günümüzün en popüler konularından biri haline gelen e-ticaret, ilk defa ortaya çıktığı 1960'lı yıllardan itibaren işletmelerin operasyonel faaliyetlerinde önemli değişikliklere sebebiyet vermiştir. E-ticareti geleneksel ticaretten ayıran en önemli fark neredeyse tüm iş yapma biçimlerinin internet üzerinden gerçekleşmesidir. E-ticaret işletmeler için yeni pazarlar yaratmak, gelirleri arttırmak, tedarikçi iletişimini geliştirmek, müşteri sadakatini yükseltmek, aracı olmadan satış yapabilmek, stok ve nakliye maliyetlerini azaltmak gibi fırsatlar sunarken, tüketiciler için zamandan tasarruf, esnek ödeme seçenekleri, istenilen yer ve zamanda alışveriş yapabilme, düşük işlem maliyetleri ve esnek ödeme seçenekleri gibi faydalar sağlamaktadır (Gedik, 2021:185). Covid-19 salgınının etkisiyle tüketiciler evde kaldıkça dijital alışveriş kanallarına daha çok yönelmişlerdir. 2020'de iki milyardan fazla tüketici mal ve hizmet satın almış ve e-perakende satışlarının dünya çapındaki toplam tutarı 4,28 trilyon \$'ı aşmıştır. Bu rakamın 2022'de 5,4 trilyon \$'a ulaşması tahmin edilmektedir. 2021 yılı e-ticaret verilerine göre tüketicilerin çevrimiçi etkinliklerinin başında çevrimiçi alışveriş gelmekte ve 2020-2024 yılları arasında yıllık \%20,2 bileşik büyüme oranıla perakende e-ticaret gelişimi açısından ilk sıradaki ülkenin Türkiye olacağı öngörülmektedir (Statista, 2021a). Dünya genelinde en popüler çevrimiç̧i alışveriş kategorileri ise giyim, ayakkabı ve tüketici elektroniği şeklindedir (Gedik, 2021:185).

İnternetin kullanımı ve yaygınlaşmasıyla birlikte neredeyse tüm ticaret alanları bundan etkilenmiştir. Turizm, internet teknolojilerinden en fazla etkilenen alanların başındadır ve internet teknolojilerinin benimsenmesinde havayolu şirketlerinden sonra seyahat acenteleri ilk sıralarda gelmektedir (Temizkan ve Özhasar, 2020:118). Uluslararası çevrimiçi seyahat acentesi sektörünün pazar büyüklügü 2019 yılında 744,73 milyar \$’a ulaşmıştır. Bu rakamın Covid-19 salgını nedeniyle dünya genelindeki seyahat kısıtlamalarından dolayı 2020 yılında 595,78 milyar \$'a gerilemesi beklenmekle birlikte salgını kontrol altına alacak önlemlerin uygulanmasına bağlı olarak 2023 yılına kadar kademeli olarak yıllık yaklaşık \%11 büyüme ile 820,18 milyar \$'a ulaşması beklenmektedir (Statista, 2020). Salgın öncesi verilerine göre 2019 yılında 15,07 milyar \$ gelir ile dünyada en yüksek gelire sahip çevrimiçi seyahat acentesi iştiraki olan Booking Holdings sadece 2019 yılı Temmuz ayında 697 milyon ziyaretçi trafiği rakamına ulaşmıştır. Booking Holdings'i aynı yıl 12,07 milyar \$ gelir ile Expedia Group takip etmiştir. 2020 yılı gelirleri incelendiğinde ise Booking Holdings gelirleri yaklaşık 6,8 milyar \$'a düşerken, Expedia gelirleri de yaklaşık 5,2 milyar \$ şeklinde gerçekleşmiştir (Statista, 2021b). Bu bilgiler salgın dönemi haricinde çevrimiçi seyahat pazarının her geçen yıl hızla gelişmekte olduğunu göstermektedir.

Çevrimiçi Seyahat Rezervasyon İstatistikleri 2020 raporuna göre, tatil tüketicilerinin \% $900^{\prime} 1$ tüm tatil araştırmalarını çevrimiçi yapmakta ve \%80'i ise rezervasyonlarını çevrimiçi gerçekleştirmektedir. Google Trends verilerine göre uçuşlar ve oteller 12 hafta öncesinden rezerve edilebilmektedir. Bu durum bir geziden önceki 12 hafta içinde arama eğilimlerinin başladığını ve deneyimlerin gezginlerin ana odak noktası olduğunu göstermektedir. 2019 yılı Temmuz ayında 224 milyon ziyaretçi trafiği çeken TripAdvisor internet sitesi, ziyaretçilerinin \% 80 'inin dört haftasını diğer gezginlerin yorumlarını okuyarak ve bir varış noktası araştırarak geçirdiğini belirlemiştir. Buna karşın raporda yer alan başka bir araştırmada ABD'li gezginlerin \% 51'inin bir seyahate karar verdiklerinde araştırma yapmak için bir haftadan daha az zaman geçirmek istedikleri tespit edilmiştir. Ayrıca ABD'li yetişkin gezginlerin \% 83'ünün seyahatlerini çevrimiçi olarak rezerve etmeyi tercih ettiği ve \% 33'ünün bir sonraki seyahatlerinde planlamalarına yardımcı olması için çevrimiçi seyahat asistanı kullandıkları belirlenmiştir. Yine Google Trends verilerine göre "bu gece" ve "bugün" dahil olmak üzere seyahat ile ilgili aramalar son beş yılda \%519'dan fazla artış göstermiştir. Bunlara ilave olarak mobil rezervasyonların $\% 72$ sinin son dakika Google aramalarından sonraki 48 saat içinde gerçekleştiği belirlenmiştir. Gezginlere "tek durak noktası" sunan çevrimiçi seyahat acentelerinin 2020 yılı itibariyle çevrimiçi 
dijital seyahat pazarının \%41'ine sahip olması beklenmektedir. Bununla birlikte Y kuşağının otel rezervasyonlarını seyahat acenteleri aracılığıyla yapmayı tercih etmesine rağmen $\% 52$ 'sinin daha fazla bilgi için otellerin web sitelerini de incelediği belirlenmiştir (Condor Ferries, 2021).

Yukarıdaki bilgiler ışığında turistlerin \%90'nın tatil kararından önce çevrimiçi araştırma yaptıkları ve geçmiş turist deneyimlerinin destinasyon seçimi konusunda karar vermede önemli olduğu görülmektedir. Tatil kararına yönelik araştırma süreçleri 12 hafta öncesinden varış gününe kadar değişiklik gösterebilmekte ve son dakika seyahat aramalarında artış görülmektedir. Çevrimiçi gerçekleşen rezervasyon oranı ise \%80 düzeyindedir. Turistlerin çevrimiçi tatil kararında deneyimler gibi önemli olan bir diğer konu seyahat internet sitelerindeki sıralama listeleridir (TripAdvisor, 2020). Turistlerin çevrimiç̧i rezervasyonlarına ilişkin olarak en çok ziyaretçi trafiği ve en yüksek rezervasyon dönüşüm oranı (conversion rate), siralamalarda daha üst sıralarda yer alan otellerde gerçekleşmektedir (Doğan, 2021). Bununla birlikte oteller ilgili sıralama listelerinde birbirleriyle sıkı bir rekabet içerisine girdiklerinden sürekli daha üst sıralara ulaşabilme hedefindedirler (Vignieri, 2013). Bu durum turizmde çevrimiçi sıralamaların hem işletmeler hem de turistler için önemli bir hale gelmesini sağlamıştır. Bu araştırmanın amacı otel tercihinde dünyada en yüksek gelire sahip Booking.com çevrimiçi seyahat acentesindeki İstanbul otelleri sıralama listesinde yer alan ilk 7 otelin sıralaması ile otellerin ayn internet sitesindeki misafir görüşlerinde bulunan kriter puanlarına yönelik AHP ve PROMETHEE Çok Kriterli Karar Verme (ÇKKV) yöntemleri uygulanarak oluşan tercih sıralaması arasında farklılık olup olmadığını belirlemek ve farklılıklar var ise bunun nedenlerini ortaya koymaktır.

\section{KAVRAMSAL ÇERÇEVE}

\section{Booking.com Misafir Değerlendirmeleri ve Tesis Görünürlükleri}

1996 yılında küçük bir Hollanda girişimi olarak Amsterdam'da faaliyetlerine başlayan Booking.com dünyanın lider dijital şirketlerinden biri haline gelmiştir. 2019 yılında 15,07 milyar \$ gelir elde eden şirketin gelirleri 2020 yılında salgın sebebiyle artan kısıtlamalara bağlı olarak satışlarında gerilemeler kaydederek 6,08 milyar \$'a gerilemiştir. Fakat önceki yıllarda da olduğu gibi dünyanın en çok gelir elde eden çevrimiçi seyahat acentesi olarak liderliğini sürdürmektedir (Statista, 2021b). Booking.com, çevrimiçi seyahat acentesi ile ilgili hizmetlerde faaliyet gösteren Booking Holdings iştirakinin bir parçasıdır. İştirakte Booking.com ile birlikte PriceLine.com, Agoda.com, Kayak.com, RentalCars.com ve OpenTable.com internet siteleri yer almaktadır. Misyonu herkesin dünyayı keşfetmesini kolaylaştırmak olan Booking.com dünya çapında 198 ofis tarafından 70 ülkede 43 dilde 7/24 desteklenmekte ve 6,2 milyondan fazla ev, daire ve diğer konaklama yerleri olmak üzere 28 milyonun üzerinde konaklama hizmet birimi sunmaktadır (Booking, 2021a).

Booking.com 2017 yılında Türkiye'de en düşük konaklama fiyatlarını internet sitesinde garanti etmesine ilişkin haksız rekabete neden olması ve vergi ödememesi gerekçesiyle Türkiye Seyahat Acenteleri Birliği (TÜRSAB) tarafından mahkeme kararıyla kapatılmıştır. Böylelikle Booking.com üzerinden Türkiye otelleri için rezervasyonlar sadece yurtdışı aramalardan gerçekleşmeye başlamıştır. Ekim 2020'de ise Booking.com yetkilileri Türkiye'den elde edilen ciro üzerinden \%7,5 vergi ödemeyi kabul ettiklerini, Türkiye'de ofis açmak için çalışmalarını hızlandırdıklarını ve satış sloganlarını değiştireceklerini açıklamışlardır (Turizm Ajansı, 2020). Bu gelişmeler incelendiğinde Türkiye'nin uluslararası turizm pazarında iç pazar dahil olmak üzere vazgeçilmez bir turizm destinasyonu olduğunu göstermektedir. 


\section{Booking.com Misafir Değerlendirmeleri}

Booking.com, misafir görüşlerini misafirlerin konaklama işletmelerinden ayrılışından hemen sonra kendilerine e-posta yoluyla erişim bağlantısı göndererek talep etmektedir. Bu değerlendirme için misafirlere 90 gün süre tanınmaktadır. Misafirler, tesisteki deneyimlerini puanlamada 1 ila 10 arasında bir genel puan seçebilmektedirler. Misafirlerin değerlendirmelerini gönderebilmeleri için yanıtlamaları zorunlu olan tek soru bu genel değerlendirme bölümüne ilişkindir. İlgili genel puanların ortalaması ise tesislerin "Konuk Değerlendirme Puanı" olmaktadır. Konuk değerlendirme puanı, tesislerin Booking.com otel sıralama listesindeki konumuna etki etmektedir ve tesis görünürlügünün artmasını veya azalmasını sağlayan faktörler arasındadır (Booking, 2021b). Booking.com internet sitesinde tesis görünürlüğüne etki eden tüm faktörler bir sonraki bölüm olan tesis görünürlükleri başlığı altında detaylıca belirtilmiştir.

Konuk değerlendirme puanı dışında değerlendirmelerin daha ayrıntılı olabilmesi amacıyla misafirlerin kendi istekleriyle katılım sağlayabileceği Booking.com tarafından belirlenen 6 değerlendirme kriteri de misafirlerin görüşüne sunulmaktadır. Burada da misafirler her bir kriter için 1 ila 10 arasında bir değerlendirme puanı seçebilmektedirler. Bu kriterler Temizlik, Rahatlık, Fiyat/Fayda Dengesi, Olanaklar, Konum ve Personel kriterlerinden oluşmaktadır. Kriterlere ilişkin puanlamalar misafirlerin isteğine bağlıdır ve konuk değerlendirme puanına dahil edilmemektedir. Söz konusu 6 kriterin dişında yine misafirlerin isteğine bağlı olarak farklı misafirler için çeşitli konularda da Ücretsiz WiFi, Kahvaltı, Gürültü Düzeyi gibi ilave kriterlere yönelik değerlendirmeler Booking.com tarafından misafirlere sunulmaktadır (Booking, 2021b).

2019 yılı sonuna kadar Booking.com misafir görüşlerine ilişkin değerlendirmelerde konuk değerlendirme puanını yukarıda bahsedilen tüm kriterlerin ortalaması üzerinden oluşturmuştur. 2019 yılı son dönemlerinden itibaren ise Booking.com değerlendirme stratejisini değiştirerek sadece tek bir katılımla genel değerlendirme puanının oluşabilmesini sağlamış ve diğer alt kriterlerin genel puanlamada olan etkisini ortadan kaldırmıştır. Bunun sebeplerini araştırmak ayrı bir araştırma konusu olabilir. Fakat Booking.com bu değişikliğin nedenlerini açıklarken örneğin tesis konumu gibi değişmez kriterlerin tesisler tarafından doğrudan kontrol edilememe durumunu ve misafir görüşlerindeki kriterlerin her bir misafir için aynı derecede öneme sahip olmayabileceğini ifade etmektedir. Bununla birlikte Booking.com, misafir görüşlerindeki bu güncel değerlendirme stratejisini bir misafirin değerlendirmesinde dikkate alabileceği bazı hususların ilgili alt kriterlere dahil olamayabileceğini vurgulamaktadır ve bundan dolayı genel puanın, kriterlerden elde edilen puanlardan farklı olmasının normal olduğu anlamına geldiği şeklinde açıklamaktadır. Ayrıca Booking.com misafir değerlendirmelerine ilişkin uygulamaya aldığı bu yeni stratejilerine ilave olarak daha az yeni değerlendirme alan bazı tesislerin geçmiş değerlendirmelerinin iki yıl içerisinde arşivlenmesi uygulamasından olumsuz etkilendiğini tespit ederek mevcut değerlendirmeler de dahil olmak üzere misafir görüşlerinin internet sitesindeki geçerlilik sürelerini üç yıl şeklinde uzatmıştır (Booking, 2021b).

\section{Booking.com Tesis Görünürlükleri}

Booking.com internet sitesinde yer alan oteller arasında en fazla rezervasyon trafiği, sıralama listelerinde yer alan öncelikli sayfalarda ve tercihli ortak programına katılan tesislerde oluşmaktadır. Bununla birlikte Booking.com tesislere sıralamalarda daha üst sıralarda nasıl yer alabileceklerine ilişkin uygulanması gereken stratejileri sürekli geliştirerek sunmaktadır. Buna bağlı olarak Booking.com tesislere arama sonuçlarında ne kadar fazla sayıda görünürlerse tesis sayfalarına misafir çekebilme ve rezervasyon alabilme şanslarının o kadar fazla olduğunu belirtmektedir. Bu doğrultuda Booking.com tesislere internet sitesinde içerik, kontenjan, fiyat vb. 
bilgileri yükleyebildikleri "Extranet" sisteminde "Görünürlük Paneli" hizmeti vermektedir. Böylelikle tesisler Booking.com arama sonuçlarındaki görünürlüklerini izleyip yapılması gereken iyileştirmelere ilişkin verileri elde edebilmektedirler. Bu veriler; görünürlük performansı ve kendi tesislerini diğer tesislerle kıyaslayabilme ile rezervasyon dönüşüm oranı biçimindedir. Böylece tesisler bu önemli veriler işığında eyleme geçerek daha fazla potansiyel misafire görünürlüklerini arttırabilme fırsatı yakalayabilmektedirler (Booking, 2021c).

Görünürlük panelindeki en önemli göstergeler misafir yolculuğunun ilk aramadan rezervasyon yapmaya kadar tamamını kapsayan verilerden oluşmaktadır. Tesisler görünürlük panellerinde, potansiyel misafirlerin tesislerini arama sonuçlarında kaç defa gördüğü "Arama Sonuçları Görüntülemeleri"ne, arama sonuçlarına ilişkin görüntülenme sayısına göre tesisi ziyaret eden potansiyel misafirlerin yüzdelik "Tıklama Oranı"na, potansiyel misafirlerin tesis sayfasını kaç defa görüntülediği "Tesis Sayfası Görüntülemeleri"ne ve iptaller dahil alınan toplam rezervasyon sayısı olan "Rezervasyonlar"a ilişkin detaylı verilere ulaşabilmektedirler. Tesisler bu verileri 30, 90 ve 365 günlük grafikler ile birlikte geçen yıl verileriyle de kıyaslayabilmektedirler. Booking.com son 90 gündeki tesis verilerine göre her tesis için "Arama Sonuçları Performans Puanı" vermektedir. $\mathrm{Bu}$ puan tesisin diğer tüm tesislere göre siralamasının nerede olduğunu göstermektedir (Booking, 2021c). Booking.com internet sitesinde tesislerin "Görünürlük Performanslarını" en fazla etkileyen faktörler Tablo 1'de yer almaktadır.

Tablo 1. Booking.com İnternet Sitesinde Görünürlük Performanslarını En Fazla Etkiyen Faktörler

\begin{tabular}{|c|c|}
\hline Faktörler & Açıklama \\
\hline $\begin{array}{l}\text { Rezervasyon Dönüşüm Oranı } \\
\text { (Conversion Rate) }\end{array}$ & $\begin{array}{l}\text { Gerçekleşen rezervasyonların tesis sayfası } \\
\text { görüntülenme sayısına göre yüzdelik oranıdır. } \\
\text { Görünürlük paneli bu oranı tesis pazarı } \\
\text { ortalamasıyla karşılaştırmaktadır. Dönüşüm oranı, } \\
\text { tesisin rezerve edilme olasılığını tahmin etmede } \\
\text { yardımcı olduğundan çok önemlidir. }\end{array}$ \\
\hline $\begin{array}{l}\text { Ortalama Günlük Fiyat } \\
\text { (ADR: Avarage Daily Rate) }\end{array}$ & $\begin{array}{l}\text { Belirli bir dönem içerisinde dolu oda başına ödenen } \\
\text { ortalama oda geliridir. Görünürlük paneli bu oranı } \\
\text { tesis pazarı ortalamasıyla karşılaştırmaktadır. }\end{array}$ \\
\hline İptal Oranı & $\begin{array}{l}\text { Son } 90 \text { gün içerisinde iptal edilen rezervasyonların } \\
\text { yüzdelik oranıdır. Görünürlük paneli bu oranı tesis } \\
\text { pazarı ortalamasıyla karşılaştırmaktadır. }\end{array}$ \\
\hline Tesis Sayfası Puanı & $\begin{array}{l}\text { Tesis içeriğinde yer alan fotoğraflar, özellikler, oda } \\
\text { bilgileri, açıklamalar ve board tipleri gibi bilgilerin } \\
\text { potansiyel misafirler için ne kadar çekici ve faydalı } \\
\text { olduğunu göstermektedir. }\end{array}$ \\
\hline Fiyat Kalitesi Puanı & $\begin{array}{l}\text { Tesisin diğer satış kanallarındaki en düşük fiyatları } \\
\text { ile booking.com'daki fiyatlarının karşılaştırılma } \\
\text { durumuna ilişkin puan türüdür. }\end{array}$ \\
\hline Değerlendirme Puanı & $\begin{array}{l}\text { Geçmişteki misafirlerin tesisteki deneyimlerine } \\
\text { yönelik memnuniyetlerinin ne derecede olduğunu } \\
\text { göstermektedir. }\end{array}$ \\
\hline
\end{tabular}

Kaynak: Booking, 2021c

Tesislerin yukarıda bulunan faktörleri iyileştirerek görünürlüklerini arttırabilmelerinin yanında booking.com'da belirli bir performans elde ederek katılım sağlayabilecekleri görünürlük arttırıcı iki program daha bulunmaktadır. Bu programlara katılım için tesislerin gelir ve özel uygunluk 
kriterlerini karşılamaları gerekmektedir. Bu programlar; tesise en sık rezervasyon yapan misafirlere özel indirimler sunulmasına yönelik olan "Genius Programı" ve daha yüksek performansa sahip tesislere özel bir başparmak onay simgesinin verildiği "Tercihli Ortak Programı" şeklindedir. Tesislerin tercihli ortak programına dahil olabilmesi için bazı kriterler bulunmaktadır. Bunlar; booking.com'daki satış fiyatlarının diğer satış kanallarına göre yüksek olmaması, odaların her zaman satılabilir olması, komisyon faturalarının tesis tarafından booking.com'a zamanında ve düzenli ödenmesi, misafir genel değerlendirme puanının minimum 7,0 olması, rezervasyon dönüşüm oranının yüksek ve iptal oranının düşük olması şeklindedir. Ayrıca tesisler yüksek talep aldıkları belirli tarihlerle birlikte düşük satış veya yüksek iptal yaşadıkları dönemlerde görünürlüklerini öne çıkarmak amacıyla "Görünürlük Arttırıcı" yı da kullanabilmektedirler (Booking, 2021c). Genius programında misafirlerine özel indirimler sunarak görünürlüklerini arttırabilirken, tercihli ortak programında booking.com'a ödedikleri ortalama \%15 olan komisyon oranlarını \%20'lere kadar çıkartmayı kabul etmektedirler. Görünürlük arttırıcı da ise komisyon oranlarını hedef pazarlarında farklılaştırmak dahil olmak üzere \%50’lere kadar çıkartarak sıralamalarını yükseltebilmektedirler (Booking, 2021d).

Yukarıdaki bilgiler ışığında Booking.com sıralamalarının oldukça dinamik bir yapıda olduğu görülmektedir. Tüm bunlara ilave olarak potansiyel misafirlerin geçmiş arama davranışları da sıralamalara etki eden diğer bir etkendir. Bu durum misafirlerin ihtiyaçları ile doğru türde müsait tesislerin eşleştirilebilmesini kolaylaştırmaktadır. Başka bir ifadeyle booking.com tüm misafir tipleri için aynı tesis sıralamasını sunmaktansa misafirlerin arama tercihleriyle alakalı sonuçları potansiyel misafirler için daha da kişiselleştirilmiş bir şekilde sıralama gayreti içerisinde olduğunu belirtmektedir. Özet olarak sıralama sonuçları tesislerin Booking.com internet sitesindeki genel performansı, belirli pazar dinamikleri ve site ziyaretçilerinin geçmiş arama davranışlarını dikkate alarak misafirlerin belirli tercihleriyle ilişkili faktörlere göre sıralanmaktadır (Booking, 2021e). Fakat daha öncede bu çalışmada misafir değerlendirmeleri bölümünde Booking.com tarafından belirtildiği gibi 2019 yılından itibaren misafir görüşlerinde genel değerlendirmenin altında yer alan Temizlik, Rahatlık, Fiyat/Fayda Dengesi, Olanaklar, Konum, Personel, Ücretsiz WiFi ve Gürültü Düzeyi gibi alt kriterlerin puanları misafirlere sunulsa da sıralamalarda herhangi bir etkisi bulunmamaktadır. Bu çalışmada İstanbul otellerinin Booking.com ilk açılış sayfasında sunulan "Popüler Seçimlerimiz" sıralama listesindeki ilk 7 oteli alternatif oteller olarak belirlenmiştir. Belirlenen otellerin konuk değerlendirmeleri bölümünde genel değerlendirme puanın altında bulunan Temizlik, Rahatlık, Fiyat/Fayda Dengesi, Olanaklar, Konum, Personel ve Ücretsiz WiFi olmak üzere toplam 7 kritere ilişkin misafir değerlendirme puanları araştırma kapsamında belirlenen alternatif otellerin Booking.com üzerindeki sayfalarında içerik analizi yapılarak elde edilmiştir. Elde edilen kriter değerlendirme puanlarına ilişkin veriler PROMETHEE yöntemi ile tercih sıralamalarının belirlenebilmesinde kullanılmıştır.

\section{Turizmde Çok Kriterli Karar Verme Yöntemleri Kullanılarak Yapılan Örnek Araştırmalar}

ÇKKV yöntemleri, çok seçenekli problemlerin çözümünde karar vericilerin karşılaştıkları kaotik durumlarda başvurdukları, problem çeşitlerine göre farklı tipleri olan karar destek teknikleridir. $\mathrm{Bu}$ tekniklerde alternatif sıralamalar veya çoklu seçenekler içerisinden seçimler yapma şeklinde çözümlemeler gerçekleştirilmektedir. Her bir karar verme yönteminin metodolojisini oluşturan kendine özgü bir yaklaşım ve kullanım şekli bulunmaktadır (Karahan ve Peşmen, 2020:277). Uygulamalarda sıklıkla kullanılan ÇKKV yöntemleri Analitik Hiyerarşi Prosesi (AHP), Ağırlıklı Toplam Metodu (ATM), Ağırlıklı Çarpım Metodu (AÇM), TOPSIS, VIKOR, ELECTRE ve 
PROMETHEE olarak sıralanabilir (Karaca, 2011). Literatürde ÇKKV yöntemlerinin turizm alanında uygulandığı çeşitli araştırmalar bulunmaktadır.

2009 yılında Antalya/Belek bölgesinde faaliyet gösteren 6 otel, 7 kriter üzerinden AHP yöntemiyle değerlendirilerek tercih sıralaması oluşturulmuştur (Adıgüzel vd., 2009). Başka bir araştırmada Kapadokya'daki 5 yıldızlı 4 alternatif otelin tercihinde 5 kriter üzerinden AHP yöntemiyle değerlendirilme yapılmıştır. Araştırmada kriterlerin ağırlıklandırılmasında seyahat acenteleri yetkililerine anket tekniği uygulanmıştır (Doğan ve Gencan, 2013). 2014 yılında beş yıldızlı 16 otelin internet siteleri 5 ana kriter olmak üzere 27 alt kriter üzerinden değerlendirilerek tercih sıralamaları AHP ve PROMETHEE yöntemleri kullanılarak oluşturulmuştur (Akincilar ve Dagdeviren, 2014). 2015 yılında Konya' da faaliyet gösteren 9 alternatif otelin TripAdvisor' da yer alan puanlamasına ilişkin 6 kriter üzerinden değerlendirilmesi yapılmıştır. Araştırmada AHP tekniği ile kriter ağırlıkları hesaplanmış ve TOPSİS tekniği ile en uygun alternatif otellerin sıralamaları oluşturulmuştur (Göral, 2015). Termal otellerde en uygun tedarikçinin belirlenebilmesi amacyyla AHP ve TOPSİS yöntemlerinden faydalanarak gerçekleştirilen başka bir araştırmada 4 alternatif tedarikçi, 7 kriter üzerinden değerlendirilmiştir (Gündüz ve Güler, 2015). PROMETHEE yöntemiyle yapılan başka bir araştırmada ise Türkiye'deki A grubu seyahat acentelerinin tercih sıralamasına ilişkin 7 kriter üzerinden 5 alternatif seyahat acentesine yönelik değerlendirmeler yapılmıştır (Uygurtürk ve Korkmaz, 2015). 2016 yılında Zaman ve arkadaşları, TripAdvisor internet sitesinde yer alan 6 kriterin ağırlıkların 250 turiste anket uygulayarak AHP yöntemiyle belirlemişlerdir (Zaman vd., 2016). 2017 yılında 12 üniversite öğrencisinin Lara bölgesinde bulunan 31 otel içerisinden otel seçimine ilişkin AHP yöntemi, 7 kriter üzerinden değerlendirilerek en uygun tercih sıralamaları belirlenmiştir (Summak vd., 2017).

Çaylak 2019 yılında TOPSIS yöntemiyle Antalya bölgesinde faaliyet gösteren bir zincir oteller grubunun 11 otelini 9 kriter üzerinden en uygun olanının belirlenmesi çalışmasını yapmıştır (Çaylak, 2019). 2019 yılında sağlık turizmine yönelik AHP yöntemiyle gerçekleştirilen bir başka araştırmada, klinik çeşitlerine göre İstanbul ve Mersin illeri 9 kriter üzerinden kıyaslanarak değerlendirilmiştir (Sonel vd., 2019). Turizmde ürün seçimi konusunda MOORA yöntemiyle Uşak ilinde faaliyet göstermekte olan bir otel işletmesinin ürün tercihinde dikkat etmesi gereken 5 kriter, 5 alternatif arasından en iyi tercihin belirlenebilmesine yönelik yapılmıştır (Şimşek ve Çatır, 2020). Karma bir yöntem ile Manap Davras'ın (2020) yaptığı bir araştırmada rekabet gücü açısından Akdeniz turizm destinasyonları değerlendirilmiştir. Destinasyonların 12 kriter üzerinden değerlendirildiği araştırmada kriter ağırlıkları AHP yöntemiyle belirlenerek 16 Akdeniz turizm destinasyonun TOPSIS ve VIKOR yöntemleriyle rekabet gücü sıralaması yapılarak sonuçlar karşılaştırılmıştır (Manap Davras, 2020). 2020' de turist rehberi seçiminde AHP yöntemi kullanılarak 7 alternatif rehber içerisindeki en uygun rehber, 7 kriter üzerinden belirlenmiştir (Gökdemir ve Eren, 2020). Başka bir araştırmada Elazığ ve komşu illeri arasındaki rekabeti belirlemede PROMETHEE GAIA tekniği kullanılmıştır (Karahan ve Peşmen, 2020).

ÇKKV yöntemlerine yönelik turizm alanında gerçekleştirilen yukarıdaki örnek araştırmalar incelendiğinde araştırmaların çeşitli konular üzerinde çalışıldığı görülmektedir. Bu konular otel seçimi, tedarikçi seçimi, bölge sağlık turizmi altyapısı, turist rehberi seçimi ve destinasyon rekabet gücü şeklindedir. İlgili araştırmalarda kullanılan ÇKKV yöntemleri ise AHP, PROMETHEE, TOPSİ, VIKOR ve MOORA teknikleridir. Araştırmaların genelinde belirlenen kriterlerin ağırlıklandırılmasında anket tekniğiyle uzman görüşünden faydalanılmıştır. Bu araştırma kapsamında otel tercih sıralamasının belirlenebilmesine yönelik Booking.com internet sitesinde yer alan 7 kriterin (Temizlik, Rahatlık, Konum, Olanaklar, Çalışanlar, Fiyat/Fayda Dengesi, Ücretsiz WiFi) ağırlıklarının tespit edilebilmesi için uzman görüşüne başvurularak turizmde dijital pazarlama alanındaki yetkililere anket tekniği uygulanmıştır. Booking.com İstanbul sayfasındaki otel listesinde yer alan ilk 7 otel alternatif oteller olarak seçilerek kriter 
ağırlıkları AHP yöntemiyle belirlenmiş ve PROMETHEE yöntemiyle de alternatiflerin tercih sıralaması oluşturulmuştur. Literatür incelemesinde otellerin Booking.com satış listesindeki sıralamalarının aynı internet sitesinin kriterleri üzerinden ÇKKV yöntemleriyle belirlenen karşılaştırmalarına yönelik bir araştırmaya rastlanılmamıştır. Araştırmanın amacı misafir görüşlerine ilişkin kriter değerlendirmelerinden elde edilen üstünlük sıralamaları ile internet sitesinde sunulan sıralamalar arasında farklılık olup olmadığını ve eğer farklılıklar var ise nedenlerini belirlemektir. Araştırmanın bu konuda literatüre katkı sağlayacağı öngörülmektedir.

\section{YÖNTEM}

Bu çalışmada İstanbul'da faaliyet gösteren Booking.com "Popüler Seçimlerimiz" sıralamasındaki ilk 7 otel araştırma alternatifleri olarak belirlenmiştir. Araştırma kriterleri olarak ise İstanbul otelleri için Booking.com misafir görüşleri bölümünde siteyi ziyaret eden potansiyel misafirlere sunulan 7 değerlendirme alt kriterinin tamamı sitedeki isimlendirmelerinde olduğu gibi Temizlik, Rahatlık, Fiyat/Fayda Dengesi, Olanaklar, Konum, Personel ve Ücretsiz WiFi şeklinde alınmıştır. Kriterlerin önem ağırlıklarının belirlenmesinde 10 dijital pazarlama yetkilisinin uzman görüşüne anket yoluyla başvurulmuştur. Kriterlerin ağırlıklandırılmasında AHP, belirlenen ağırlıklara ilişkin otel sıralamasının oluşturulmasında ise PROMETHEE yönteminden yararlanılmıştır.

Bu çalışmada kullanılan anket ölçeği, İskenderun Teknik Üniversitesi Bilimsel Araştırma ve Yayın Etiği Kurulu tarafından değerlendirilerek etik ilke ve kurallara uygun bulunmuştur (Kurul Karar Tarihi: 26.01.2021, Toplantı No: 13).

\section{Analitik Hiyerarşi Prosesi (AHP)}

Günümüzde iş hayatındaki çeşitli alternatiflerin bulunduğu durumlarda veya yoğun rakabet ortaminda en uygun kararların karar verme yöntemleriyle desteklenerek verilmesi önemlidir (Göral, 2015:4). ÇKKV teknikleri arasında en sık kullanılanlarından biri olan Analitik Hiyerarşi Prosesi (AHP) yöntemi ilk kez Mysers ve Albert tarafından 1968 yılında ortaya çıkarılmıştır (Gündüz ve Güler, 2015:208). Thomas H. Saaty tarafından 1977 yılında geliştirilen teknik çok sayıda alanda başarıyla kullanılmaktadır. AHP tekniği karar vericinin karar verme değişkenlerine ilişkin olası karmaşık yapıya yönelik sistematik olarak çözümlemeyle hızlı tercih yapabilmesine olanak tanımaktadır (Güler, 2008:782 ). AHP tekniği ile modelleme aşamaları sırasıyla; Problemin Tanımı, Kriterlerin Ortaya Konulması, Alternatiflerin Belirlenmesi, Hiyerarşik Yapının Çizilmesi, Kriter Ağırlıklarının Hesaplanması, Alternatiflerin Her Kritere Göre Değerlendirilmesi, Her Alternatifin Çok Kriterli Puanının Belirlenmesi, Genel Puanların Karşılaştırılması ve En İyi Alternatiflerin Belirlenmesi şeklindedir (Aydın, 2007:358). Bu çalışmada AHP yönteminden kriterlerin ağırlık değerlerinin hesaplanması aşamasına kadar yararlanılmıştır.

AHP tekniği diğer ÇKKV yöntemlerinden farklı olarak kriterlerin birbirleriyle ikişerli karşılaştııılmasını ve bu karşılaştırmaların tutarlılığını ölçmektedir. Bu yönüyle AHP, ÇKKV problemlerinin yalın çözümünde kullanılmasının yanında çeşitli uygulama alanlarında kriter ağırlıklarının belirlenebilmesinde de tercih edilmektedir. Kriter ağırlıkları AHP ile belirlendikten sonra başka bir ÇKKV yöntemiyle sıralamalar oluşturulabilmektedir (Tayyar vd., 2014:28). AHP ile kriter ağırlıklarının belirlenmesindeki adımlar şöyledir (Ustasüleyman ve Çelik, 2015): Adım 1: Modelin Oluşturulması ve Problemin Formülizasyonu: AHP tekniğinde karar vermede etkili olan tüm nicel ve nitel faktörlerin belirlenmesinde anket çalışması yapılmakta ya da araştırma konusundaki uzmanların görüşleri alınmaktadır. Elde edilen bilgilere göre amaçlar, kriterler ve alternatifler belirlenip hiyerarşik bir model ortaya konmaktadır. Adım 2: İkili Karşılaştırmalara 
İlişkin Karşılaştırma Matrisinin Oluşturulması: Hiyerarşik model oluşturulduktan sonra ikili karşılaştırmalarda Saaty'nin 1990 yılında geliştirdiği Tablo 2' deki ölçek kullanılmaktadır.

Tablo 2. AHP Tekniğinde Kullanılan İkili Karşılaştırma Ölçeği

\begin{tabular}{cll}
$\begin{array}{c}\text { Önem } \\
\text { derecesi }\end{array}$ & \multicolumn{1}{c}{ Tanım } & \multicolumn{1}{c}{ Açıklama } \\
\hline $\mathbf{1}$ & Eşit önem düzeyinde & Her iki faaliyet hedefe eşit olarak katkıdadır. \\
\hline $\mathbf{3}$ & $\begin{array}{l}\text { Orta önem düzeyinde } \\
\text { (Az üstünlük) }\end{array}$ & $\begin{array}{l}\text { Tecrübe ve yargılara göre bir faaliyet az bir biçimde } \\
\text { diğerinden biraz daha fazla tercih edilir. }\end{array}$ \\
\hline 5 & $\begin{array}{l}\text { Güçlü önem düzeyinde } \\
\text { (Fazla üstünlük) }\end{array}$ & $\begin{array}{l}\text { Tecrübe ve yargılara göre bir faaliyet güçlü bir biçimde } \\
\text { diğerinden daha fazla tercih edilir. }\end{array}$ \\
\hline $\mathbf{2}$ & $\begin{array}{l}\text { Çok güçlü önem düzeyinde } \\
\text { (Çok üstünlük) }\end{array}$ & $\begin{array}{l}\text { Bir faaliyet diğerine göre çok güçlü bir biçimde tercih } \\
\text { edilir ve üstünlüğ̈̈ ispatlanmıştır. }\end{array}$ \\
\hline $\mathbf{2 , 4 , 6 , 8}$ & $\begin{array}{l}\text { Son derece önem düzeyinde } \\
\text { (Kesin üstünlük) }\end{array}$ & $\begin{array}{l}\text { Bir faaliyetin diğerine göre seçiminde en yüksek biçimde } \\
\text { olduğu durumdur. }\end{array}$ \\
\hline (Uzlaşma değerleri) & İki faaliyet arasında yer alan ara değerlerdir. \\
\hline
\end{tabular}

Kaynak: Saaty, 1990:15’den aktaran Ustasüleyman ve Çelik, 2015:88.

Adım 3: Kriter Ağırlıkları ve Alternatif Değerlerinin Belirlenmesi: İkili karşılaştırma matrisleri sayesinde her bir karar alternatifinin ağırlığı belirlenmektedir. Burada karşılaştırma matrisinde bulunan her bir sütunun değeri, yer aldığı sütunun toplamina bölünmesiyle matris normalleştirilmesi sağlanmaktadır. Normalleştirilen matrisin her sütununun toplamı 1 olmaktadır. Son aşamada satırda bulunan ortalamalar hesaplanarak özvektörler belirlenmektedir. Adım 4: Tutarlılı̆̆ın Hesaplanmast: Tutarlılık oranının (CR) hesaplanmasında kullanılabilen formüller şöyledir: Ağırlıkların belirlenmesinden sonra matrisin tutarlılığının kontrol edilmesi gerekmektedir. Eğer matris tutarlı değilse, belirlenen ağırlıklar kullanılamaz.

$$
A \cdot w=\lambda_{\max } \cdot w
$$

Eşitlik 1'de eşitliği sağlamakta olan max vektörü öncelikle hesaplanmalıdır. Eşitlikte $A$ karşılaştırma matrisi, $w$ belirlenen ağırlık matrisidir. Eşitlik 2'de max vektörü ile hesaplamalar yapılmaktadır. Böylelikle tutarlılığa yakınlık göstergesi olan "Tutarlılık İndeksi (CI)" belirlenmektedir.

$$
C I=\frac{\lambda \max -\mathrm{n}}{\mathrm{n}-1}
$$

CI tutarlılık indeksi belirlendikten sonra hesaplanan diğer bir değer ise "Rassallık İndeksi (RI)" dir. Farklı matris boyutlarına göre RI değeri tablo halindedir. Farklı matris büyüklüklerine göre oluşturulan rassallık indeks değerleri Tablo 3'de bulunmaktadır.

Tablo 3: Rassallık indeksleri (RI) değerleri

\begin{tabular}{|l|c|c|c|c|c|c|c|c|c|c|c|c|c|c|c|}
\hline $\mathbf{N}$ & 1 & 2 & 3 & 4 & 5 & 6 & 7 & 8 & 9 & 10 & 11 & 12 & 13 & 14 & 15 \\
\hline $\mathbf{R I}$ & 0.00 & 0.00 & 0.52 & 0.89 & 1.12 & 1.25 & 1.32 & 1.40 & 1.45 & 1.49 & 1.52 & 1.54 & 1.56 & 1.58 & 1.59 \\
\hline
\end{tabular}

Kaynak: Saaty ve Özdemir, 2003:241 
Son aşamada hesaplanan CI değerinin RI'ya oranı ile "Tutarlılık Oranı CR" belirlenmektedir. AHP tekniğinde tutarlılık oranının 0.1'den küçük olması hesaplamaların tutarlı olduğunu göstermektedir. CR değeri aşılır ise yargılar tekrar kontrol edilmelidir (Tayyar vd., 2014:29).

\section{PROMETHEE (The Preference Ranking Organization Method For Enrichment Evaluation)}

PROMETHEE yöntemi günümüzde ÇKKV teknikleri arasında en yaygın kullanılan yöntemlerden birisi haline gelmiştir. Analiz içerisindeki alternatiflerin ikili olarak karşılaştırılması ve bu karşılaştırmaların her bir kriter için daha önceden belirlenen altı sabit tercih fonksiyonundan birisinin seçilerek gerçekleştirilmesine yönelik yedi adımdan oluşmaktadır (Karahan ve Peşmen, 2020:277). PROMETHEE yöntemi ilk kez Jean Pierre Brans tarafından 1982 yılında geliştirilmiştir. Geliştirildiği ilk zamanlarda PROMETHEE I (kısmi sıralama) ile PROMETHEE II (tam sıralama) şeklinde olan yöntem, Brans ve Mareschal tarafından ilerleyen yıllarda PROMETHEE III-IV-V-VI biçiminde geliştirilmiştir. PROMETHEE yöntemi sağlık hizmetleri, bankacılık, ilaç, kimya, yatırım kararları, işgücü planlaması ve turizm gibi birçok alanda başarıyla uygulanmaktadır (Uygurtürk ve Korkmaz, 2015:144).

1988 yılında Brans ve Mareschal, PROMETHEE yönteminde elde edilen bulguların karar vericiler tarafından daha kolay yorumlanabilmesi için GAIA (Geometrical Analysis for Interactive Aid) metodunu önermişlerdir (Ömürbek ve Eren, 2016:5). PROMETHEE yönteminde uygulanabilen GAIA düzleminde ortaya konan grafik gösterim, diğer ÇKKV teknikleri gibi basit bir sıralama yapmanın ötesinde karar vericiler ve araştırmacılar için basit, anlaşılabilir ve hızlı bir bakış açısı sağlamaktadır. Bu yaklaşım ÇKKV tekniklerine farklı bir bakış açısı oluşturarak karar verme sürecine fayda sağlamaktadır (Genç, 2013:153). Sıralama problemlerini çözmede PROMETHEE I ve PROMETHEE II türleri sıklıkla tercih edilmektedir. PROMETHEE I kullanılarak belirlenen alternatiflerin kriterlerle karşılaştııılmasıyla kısmi sıralamaları oluşturulmaktadır. PROMETHEE II kullanılarak ise alternatiflerin kriterler esas alınarak karşılaştırılmasıyla net sıralamaları belirlenebilmektedir (Çelik ve Ustasüleyman, 2014:146). Yedi adımdan oluşan PROMETHEE yönteminin içerdiği formüller aşağıdadır (Ustasüleyman ve Çelik, 2015:89).

Adım 1: Alternatifler ve kriterlerin veri matrisi oluşturulmaktadır. Tablo 4'de alternatif ve kriterler ile kriter ağırlıkları ve alternatiflerin kriterlere ilişkin değerleri bulunmaktadır.

Tablo 4: Veri Matrisi

\begin{tabular}{ccccc}
\hline Alternatifler & $f_{1}$ & $f_{2}$ & $\ldots \ldots$ & $f_{\mathbf{n}}$ \\
\hline Alternatif $\mathrm{a}$ & $f_{1}(\mathrm{a})$ & $f_{2}(\mathrm{a})$ & $\ldots \ldots$ & $f_{\mathrm{n}}(\mathrm{a})$ \\
\hline Alternatif $\mathrm{b}$ & $f_{1}(\mathrm{~b})$ & $f_{2}(\mathrm{~b})$ & $\ldots \ldots$ & $f_{\mathrm{n}}(\mathrm{b})$ \\
\hline$\ldots \ldots$ & $\ldots \ldots$ & $\ldots \ldots$ & $\ldots \ldots$ & \\
\hline Alternatif $\mathrm{m}$ & $f_{1}(\mathrm{~m})$ & $f_{2}(\mathrm{~m})$ & $\ldots \ldots$ & $f_{\mathrm{n}}(\mathrm{m})$ \\
\hline Ağırlıklar & $\mathrm{w} 1$ & $\mathrm{w}_{2}$ & $\ldots \ldots$ & $\mathrm{Wn}_{\mathrm{n}}$ \\
\hline
\end{tabular}

Tablo 4'de yer alan veri matrisinde $\mathrm{m}:(1,2, \ldots \ldots, \mathrm{m})$ alternatif sayısını, $\mathrm{n}:(1,2, \ldots \ldots, \mathrm{n})$ kriter sayısını, w: her bir kritere ait ağırlık değerini ifade etmektedir.

Adım 2: Kriterlerin her birinin değerlendirilmesinde tercih fonksiyonları tanımlanmaktadır. Bu fonksiyonlar kriterlerin yapısına ve alternatiflerin niteliklerine göre seçilmektedir. PROMETHEE yönteminde altı tür tercih fonksiyonu bulunmaktadır. İlgili fonksiyonlar Olağan tip, U-tipi, Vtipi, Seviyeli tip, Lineer tip ve Gaussian tip biçimindedir ve Tablo 5'de bulunmaktadır. 
Tablo 5. Tercih Fonksiyonları

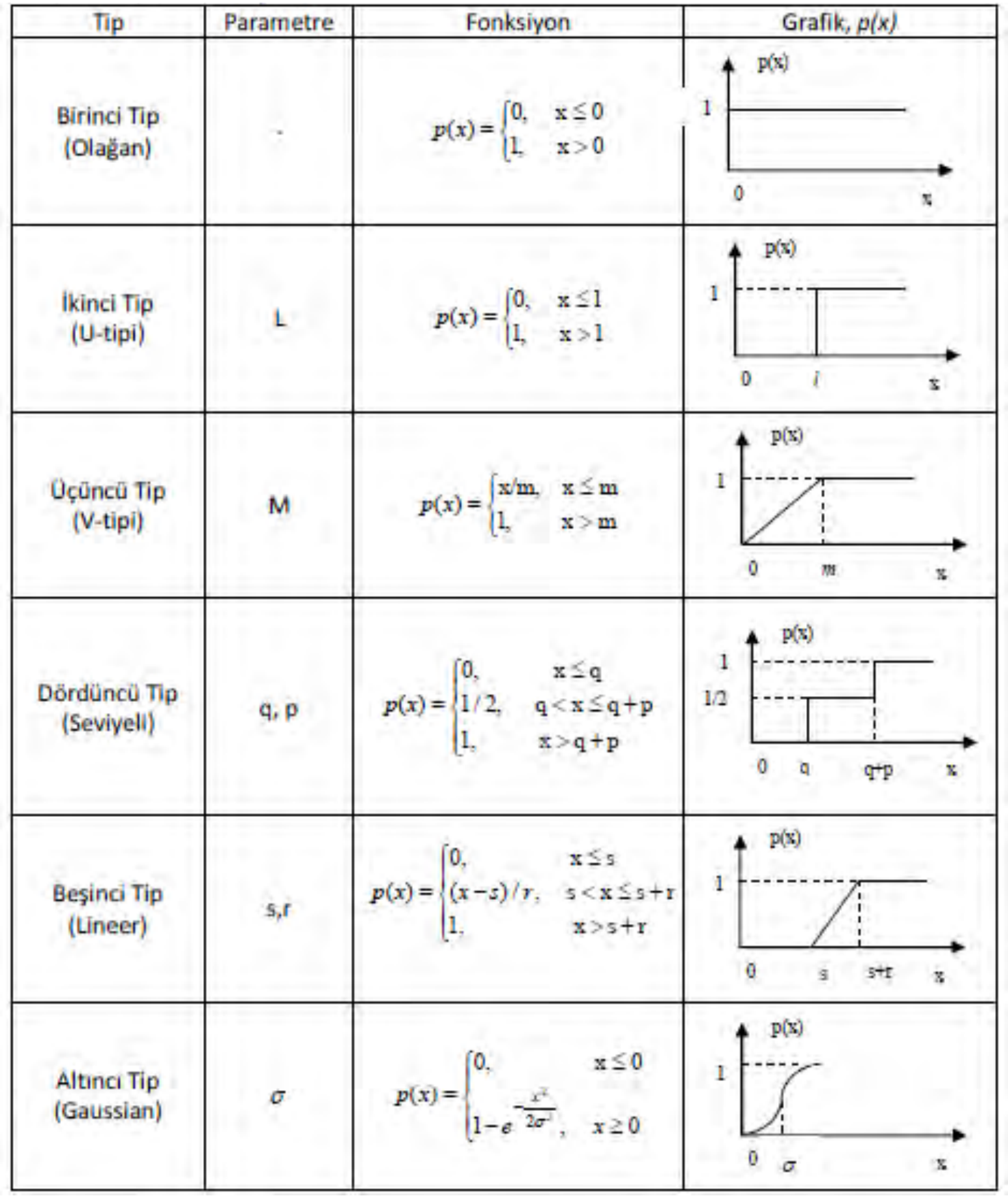

Kaynak: Brans ve Vincke, 1985'den aktaran Uygurtürk ve Korkmaz, 2015:146.

Birinci tip (Olağan) tercih fonksiyonunda değerlendirme faktörü bakımından karar verici için bir tercih fonksiyonu söz konusu olmadığı durumda ilgili değerlendirme faktörü açısından seçilmesi gereken tercih fonksiyonu Birinci Tip olmalıdır. İkinci tip (U-tipi) tercih fonksiyonunda değerlendirme faktörü bakımından karar verici kendi belirlemiş olduğu bir değerin üstünde değere sahip olan karar seviyelerinden yana tercihini kullanmak istediğinde İkinci Tip tercih 
fonksiyonunu kullanmalıdır. Karar verici, hem bir değerlendirme faktörü bakımından tercihini ortalamanın üstündeki değere sahip seviyelerden yana kullanmak istediğinde hem de ilgili değerin altındaki seviyeleri de ihmal etmek istemediğinde Üçüncü Tip (V tipi) tercih fonksiyonunu kullanmalıdır. Karar vericinin değerlendirme faktörü bakımından tercihini belirli bir değer aralığında tutmak istediği durumlarda Dördüncü Tip tercih fonksiyonu kullanılmalıdır. Beşinci tip (Lineer) tercih fonksiyonu, değerlendirme faktörü bakımından karar vericinin tercihini ortalamanın üzerinde bir değere sahip karar seviyelerinden yana kullanmak istediğinde kullanılmalıdır. Altıncı tip (Gaussian) tercih fonksiyonu ise değerlendirme faktöründeki değerlerin ortalamadan sapma değerlerinin karar vericinin tercihinde belirleyici olduğu durumlarda kullanılmalıdır (Ömürbek ve Eren, 2016:179). Ayrıca parametreler; q: farksızlık değeri, p: kesin tercih eşiği, s: $\mathrm{p}$ ve $\mathrm{q}$ arasında yer alan ara değer veya standart sapma olarak tanımlanmaktadır (Dinçer vd., 2017:109).

Adım 3: Tercih fonksiyonları baz alınarak karşılaştırılan alternatif çiftleri için ortak tercih fonksiyonları belirlenmektedir. Aşağıda $a$ ve $b$ alternatif çiftlerine ilişkin tercih fonksiyonu bulunmaktadır.

$$
P(a, b)=\left\{\begin{array}{cl}
0, & f(a) \leq f(b) \\
p[f(a)-f(b)], & f(a)>f(b)
\end{array}\right.
$$

Adım 4: Üçüncü adımda belirlenen ortak tercih fonksiyonuna yönelik her bir alternatif karşılaştırma çifti için tercih indeksleri oluşturulur. Aşağıda yer alan formül aracıllı̆̆ıyla wi $(i=1$, $2, \ldots \ldots, k)$ ağılık değerlerine sahip $\mathrm{k}$ kriter tarafından değerlendirilmekte olan a ve $\mathrm{b}$ alternatiflerine ilişkin tercih indeksi hesaplanmaktadır.

$$
\pi(\mathrm{a}, \mathrm{b})=\frac{\sum_{i=1}^{k} w_{i} * P_{i}(a, b)}{\sum_{i=1}^{k} w_{i}}
$$

Adım 5: Pozitif üstünlükler $\left(\Phi^{+}\right)$ve negatif üstünlükler $\left(\Phi^{-}\right)$her bir alternatif için belirlenmektedir.

$$
\begin{gathered}
\Phi^{+}(a)=\sum \pi(a, x) x=(b, c, d, \ldots) \\
\Phi^{-}(a)=\sum \pi(x, a) x=(b, c, d, \ldots)
\end{gathered}
$$

Adım 6: Bu adımda PROMETHEE I ile kısmi öncelikler belirlenmektedir. Kısmi öncelikler ile alternatiflerin birbirlerine ilişkin tercih edilebilme durumları, birbirlerinden farksız olan alternatiflerin ve birbirleri ile karşılaştırılamayacak durumdaki alternatiflerin belirlenebilmesi sağlanmaktadır. Aşağıda a ve b gibi iki örnek alternatif için kısmi önceliklerin belirlenebilmesine yönelik durumlar bulunmaktadır (Uygurtürk ve Korkmaz, 2015:147).

$$
\begin{aligned}
& i=\Phi^{+}(a)>\Phi^{+}(b) \text { ve } \Phi^{-}(a)<\Phi^{-}(b) \\
& i i=\Phi^{+}(a)>\Phi^{+}(b) \text { ve } \Phi^{-}(a)=\Phi^{-}(b) \\
& i i i=\Phi^{+}(a)=\Phi^{+}(b) \text { ve } \Phi^{-}(a)<\Phi^{-}(b)
\end{aligned}
$$

Aşağıda a alternatifinin $b$ alternatifine göre farksız olduğu durum yer almaktadır.

$$
i=\Phi^{+}(a)=\Phi^{+}(b) \text { ve } \Phi^{-}(a)=\Phi^{-}(b)
$$

Aşağıdaki koşulların sağlanması durumlarında ise a alternatifi b alternatifi ile karşılaştırılamamaktadır.

$$
\begin{aligned}
i & =\Phi^{+}(a)>\Phi^{+}(b) \text { ve } \Phi^{-}(a)>\Phi^{-}(b) \\
i i & =\Phi^{+}(a)<\Phi^{+}(b) \text { ve } \quad \Phi^{-}(a)<\Phi^{-}(b)
\end{aligned}
$$


Adım 7: Bu adımda PROMETHEE II ile formül (11) yardımıyla alternatifler için geçerli tam öncelikler hesaplanmaktadır. Belirlenen tam öncelik değerleriyle tüm alternatifler aynı düzlem üzerinde değerlendirilerek tam sıralama oluşturulabilmektedir.

$$
\Phi(a)=\Phi^{+}(a)-\Phi^{-}(a)
$$

Aşağıda yer alan kararlar a ve b gibi iki alternatife yönelik belirlenen tam öncelik değerine bağlı olarak alınmaktadır.

$$
\begin{gathered}
\text { i. } \Phi(a)>\Phi(b) \text { ise, a alternatifi b alternatifine göre üstündür. } \\
\quad i i . \Phi(a)=\Phi(b) \text { ise, a ve b alternatifleri farksızdır. }
\end{gathered}
$$

\section{UYGULAMA}

Çalışmada potansiyel misafirlerin otel tercihinde en uygun oteli tercih edebilmelerine yönelik ÇKKV yöntemlerinden yararlanılarak, belirlenen kriterler üzerinden alternatif seçiminde tercih problemine çözüm üretilmesi amaçlanmıştır. AHP tekniği ile kriter ağırlıkları hesaplanmış, PROMETHEE tekniği ile de alternatif öncelikleri belirlenmiştir. Saaty ve Özdemir, AHP yönteminde en tutarlı ölçümlerin yapılabilmesi için araştırmada bulunması gereken alternatif ve kriterlerin sayısının 7 veya bunun iki fazlası ya da iki eksiği miktarında olması gerektiğini önermişlerdir (Saaty ve Özdemir, 2003). Bu bağlamda araştırmada 7 alternatif otel ve 7 kriter belirlenmiştir. Alternatif seçiminde 2019 yılında Türkiye'de en çok turist çeken İstanbul (T.C. Kültür ve Turizm Bakanlığı, 2019) ili otelleri araştırma evreni olarak seçilmiştir. Örneklem seçiminde ise dünyada en çok gelire sahip çevrimiçi seyahat acentesi Booking.com (Statista, 2021b) internet sitesinde İstanbul'da yer alan ve Booking.com'un site ziyaretçilerine ilk sayfada önerdiği "Popüler Seçimlerimiz" başlıklı tesisler listesindeki ilk 7 otel örneklem olarak belirlenmiştir. Alternatif olarak seçilen 7 otelin tümü Booking.com tercihli ortak programına dahil olan tesislerdir. Kriterlerin seçiminde ise Booking.com internet sitesinde her bir otelin sayfasında bulunan misafir görüşlerine ilişkin ortalama puanların yer aldığı kategorize edilmiş ve Booking.com İstanbul tesis listelemesinde sıralamalara etkisi olmayan 7 alt kriterin tümü (Temizlik, Rahatlık, Fiyat/Fayda Dengesi, Olanaklar, Konum, Personel ve Ücretsiz WiFi) kullanılmıştır.

Araştırmanın veri toplama sürecine ilişkin AHP ile kriter ağırlıklarının belirlenmesinde uzman görüşüne başvurulmuştur. AHP yöntemi sübjektif bir teknik olduğundan fazla sayıda veriye (uzmana) gereksinim duymamaktadır (Ustasüleyman ve Çelik, 2015:94) ve en az 10 örnek kullanılarak analizler gerçekleştirilebilmektedir (Lam ve Chin, 2005). Uzmanların seçiminde Yurtlu 'nun 2020 yılındaki araştırmasında belirlediği otellere yazılım hizmeti sağlayan dijital pazarlama yetkililerine ulaşılmıştır (Yurtlu, 2020). İlgili araştırmada yer alan 12 dijital pazarlama uzmanına 2021 yılı Ocak ve Şubat aylarında Saaty'nin ölçeği anket formatında sunularak katılımları sağlanmıştır. Belirlenmiş olan 12 uzmandan 10'u ankete katılım sağlamış diğer iki uzmana ise ulaşılamamıştır. Uzmanların ankete katılımları telefon ile iletişime geçilerek gerçekleştirilmiştir.

Alternatif olarak belirlenen otellerin Booking.com sıralama listesine Türkiye'den erişim kapalı olduğundan VPN (Virtual Private Network) aracilığıyla Almanya IP’leri (Internet Protocol) kullanılarak erişim sağlanmıştır. Burada Almanya'nın seçilmesinin sebebi 2019 yılında Avrupa'dan Türkiye'ye en fazla ziyaretçi gönderen ülke konumunda olmasıdır (T.C. Kültür ve Turizm Bakanlığı, 2019). Booking.com İstanbul ili “Popüler Seçimlerimiz" listesine, 4 Ocak 2021 tarihinde konaklama tarihi arama bölümüne 20-22 Ağustos 2021 günleri seçilerek ulaşılmıştır ve karşılaşılan sıralama listesindeki ilk 7 otel araştırma alternatifleri olarak belirlenmiştir. Daha sonra her bir alternatif otelin genel değerlendirme puanı altında yer alan kategorize edilmiş 
puanlarına ulaşılmıştır. İlgili puanlar bu araştırmanın "PROMETHEE Modeli Veri Matrisinin Oluşturulması" bölümünde Şekil 2' de Değerlendirmeler (Evaluations) içerisinde sunulmaktadır.

Booking.com, şehir aramalarında aynı şehir için genel ve merkez şeklinde farklı seçimler yapılabilmesine olanak tanımaktadır. Bu durum bölgeye göre listelenen toplam tesis sayısını ve buna bağlı olarak da otel sıralamalarını etkilemektedir. Araştırmada İstanbul bölgesi için tesis aramasında genel sekmesi seçilmiştir. İlgili dönemde arama sonuçlarına göre Booking.com sitesindeki İstanbul genelini kapsayan tesis sayısı 2186 adet tesis şeklindedir. Çalışmada alternatif olarak belirlenen oteller booking.com'daki sıralamalarına bağlı olarak Otel 1 , Otel ${ }_{2}$, Otel ${ }_{3}$, Otel Otel $1_{5}$, Otel 6 ve Otel şeklinde kodlanmıştır. Çalışmada kullanılan kriterler Booking.com internet sitesinde misafir görüşleri bölümünde tesislerde konaklayan deneyimli misafirler tarafından puanlanmış olan ve site ziyaretçilerine sunulan 7 kriterden oluşmaktadır. Kriterlere ilişkin olarak Temizlik; tesisin genelden özele personel dahil hijyenini, Rahatlık; tesise ilişkin sunulan hizmetlerin konforunu, Fiyat/Fayda Dengesi; konukların ödedikleri ücret karşılığında aldıkları hizmeti makul olarak görme derecesini, Olanaklar; tesiste sunulan hizmet çeşitliliğini, Konum; tesisin bulunduğu bölgedeki olanaklara erişimini, Çalışanlar; tesiste görevli tüm personeli ve Ücretsiz WiFi; tesiste sunulan ücretsiz internet erişim kalitesini açıklamaktadır.

Çalışmada takip edilen analiz aşamaları sırasıyla; Modelin Oluşturulması ve Problemin Formülizasyonu, Kriterlerin Ağırlık Değerlerinin Belirlenmesi ve Tutarlılığın Hesaplanması, PROMETHEE Modeli Veri Matrisinin Oluşturulması, Alternatiflerin Pozitif ve Negatif Üstünlüklerinin Belirlenmesi, PROMETHEE I ile Kısmi Sıralamanın Belirlenmesi, PROMETHEE II ile Tam Önceliklerin Belirlenmesi, Alternatif ve Kriterlerin GAIA Düzleminde Gösterimi, Kriterlerin Alternatifleri Etkileme Düzeyleri ve Yönleri şeklindedir. Çalışma analizleri bu sıralamaya uygun olarak aşamalar halinde aşağıda belirtilmiştir.

\section{Modelin Oluşturulması ve Problemin Formülizasyonu}

Çalışmada ilk aşamada AHP yöntemi kullanılarak araştırma problemi formüle edilmiştir. Bu doğrultuda Booking.com internet sitesinde otel seçimini etkileyen kriterler ve araştırmada belirlenen alternatiflerin yer aldığı hiyerarşik model Şekil 1'de sunulmaktadır. Oluşturulan Hiyerarşik Yapı "Super Decisions" programı kullanılarak çc̈zülmüştür.

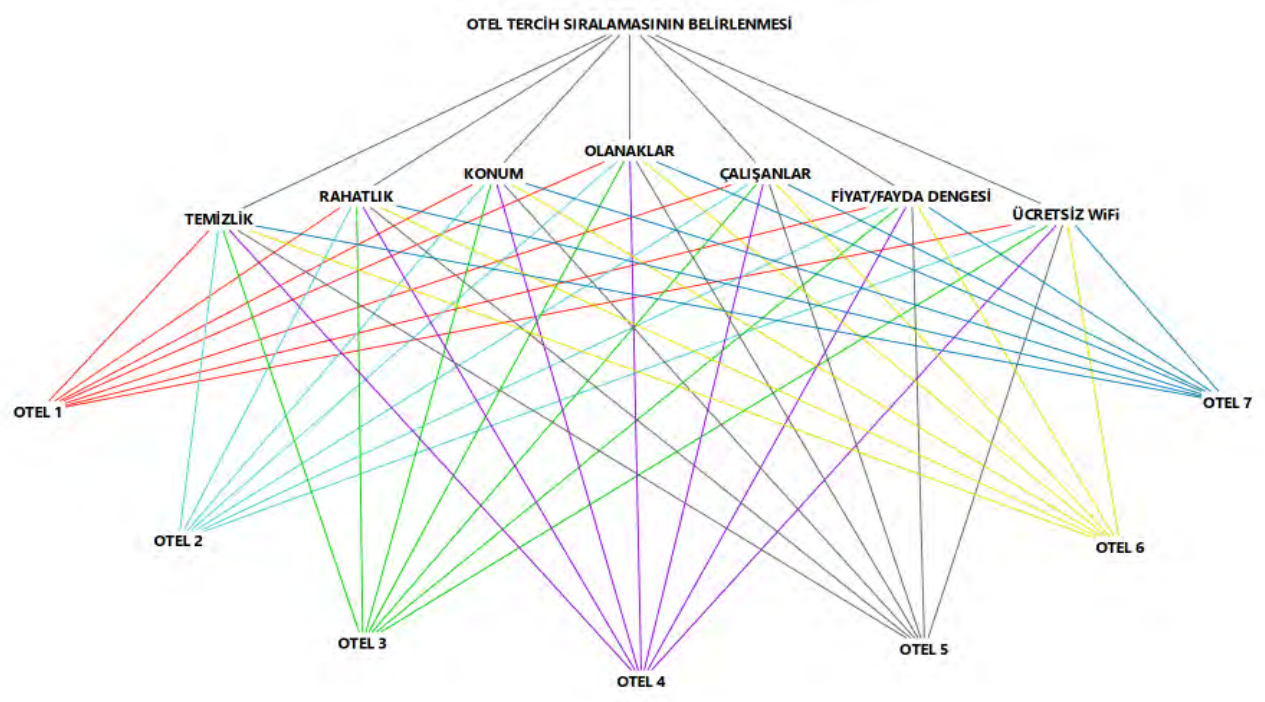

Şekil 1. Otel Tercih Sıralaması Hiyerarşik Modeli 


\section{Kriterlerin Ağırlık Değerlerinin Belirlenmesi ve Tutarlılığın Hesaplanması}

$\mathrm{Bu}$ aşamada, turizmde dijital pazarlama konusunda yetkili 10 kişinin uzman görüşü anket yoluyla alınmıştır. Ankette yer alan kriterlerin ikili karşılaştımaları Saaty'nin 1-9 ölçeği (Tablo 2.) kullanılarak hesaplanmıştır. Uzman görüşünü almada uygulanan ankete ilişkin Tablo 6'da kriterlerin ikili karşılaştırma örnekleri gösterilmektedir.

Tablo 6. Otel Tercihinin Belirlenmesinde İkili Karşılaştırma Örnekleri

\begin{tabular}{|c|c|c|c|c|c|c|c|c|c|c|c|c|c|c|c|c|c|c|}
\hline TEMIZLIIK & 9 & 8 & 7 & 6 & 5 & 4 & 3 & 2 & 1 & 2 & 3 & 4 & 5 & 6 & 7 & 8 & 9 & RAHATLIK \\
\hline KONUM & 9 & 8 & 7 & 6 & 5 & 4 & 3 & 2 & 1 & 2 & 3 & 4 & 5 & 6 & 7 & 8 & 9 & $\begin{array}{c}\text { FIYYAT/FAYDA } \\
\text { DENGESI }\end{array}$ \\
\hline TEMIZLIK & 9 & 8 & 7 & 6 & 5 & 4 & 3 & 2 & 1 & 2 & 3 & 4 & 5 & 6 & 7 & 8 & 9 & $\begin{array}{c}\text { FIYAT/FAYDA } \\
\text { DENGESI }\end{array}$ \\
\hline
\end{tabular}

Tablo 6'ya göre eğer uzman görüşü tablodaki eşitliğin (1'in) sol tarafındaysa ikili karşılaştırma değeri seçildiği gibi değerlendirilmektedir. Otel tercihinde Temizlik, Rahatlkk kriterine göre "Son derece önem düzeyinde" ise eşitliğin sol tarafında " 9" değeri seçilmektedir. Uzman görüşü eğer eşitliğin (1'in) sağ tarafındaysa ikili karşılaştırma değeri " $1 /$ " olarak değerlendirilmektedir. Tablo 6' da Otel tercihinde Fiyat/Fayda Dengesi, Konum kriterine göre "Güçlü önem düzeyinde" ise eşitliğin sağ tarafında " 5 " değeri seçilmekte olup " 1 / 5 " şeklinde değerlendirilmektedir. Eğer uzman görüşüne göre ikili karşılaştırmada kriterler "Eşit önem düzeyinde" ise " 1 " değeri seçilmekte ve seçildiği gibi “ 1 " şeklinde değerlendirilmektedir. Tablo 6'ya göre Temizlik ile Fiyat/Fayda Dengesi kriterleri ikili karşılaştırmasında kriterler eşit önem düzeyinde “ 1 " şeklinde değerlendirilmektedir.

Bireysel veya grup kararlarında AHP yöntemi uygulanabilmektedir. Eğer karar bireysel değil de bir grup karar verici ile birlikte veriliyor ise bu tekniğe "Grup Karar Verme ile AHP" denilmektedir. AHP yönteminde karar vericilerin eşit önemde olduğu durumlarda ikili karşılaştırma matrislerine ilişkin bireysel yargıların birleştirilmesinde "Geometrik Ortalama" yaklaşımı en uygun tekniktir (Göral, 2015:11). Oluşturulan hiyerarşik yapıya göre otel tercihinde kriterlerin ağırlık değerlerinin belirlenebilmesi için turizmde dijital pazarlama alanında çalışan 10 yazılım firmasındaki uzmanların yapmış olduğu ikili karşılaştırmaların geometrik ortalaması hesaplanıp birleştirilerek ortak görüş elde edilmiştir. Saaty tarafından da önerilen geometrik ortalamanın aritmetik ortalamanın yerine tercih edilmesinin nedeni karşılaştırma matrislerinde yer alan simetrik elemanların birbirlerine göre tersi olması gerektiği kuralını sağlamasıdır (Ömürbek ve Eren, 2016:58). Otel tercihinde kriterlerin ikili karşılaştırmalarına ilişkin grup kararı Tablo 7'de sunulmaktadır. Tabloda yer alan karar vericiler sütunlarda " K.V. " şeklinde kısaltılmıştır.

Araştırma kapsamında ankete katılan tüm uzmanlara ait görüşler Tablo 7'de görüldügü gibi değerlendirilerek geometrik ortalamaları hesaplanmıştır. Hesaplanan geometrik ortalama değerleri Super Decisions programının anket formuna girilmiştir. Eğer değer 1-9 arasında ise anket formunun sol tarafına değişiklik yapılmadan aynen girilmiştir. Değer ondalıklı bir sayı ise yakın olduğu tam sayı değeri şeklinde girilmiştir. Eğer geometrik ortalama değeri 0-1 arasında ise anketin sağ tarafına girilmiş olup bu değer " 1 " değerine bölünmüştür (1/0,63 gibi). Bölme işleminde hesaplanan değerin ondalıklı olması durumunda yakın olduğu tam sayı değeri " 1 / elde edilen değer" şeklinde değerlendirilmiştir (Göral, 2015:11; Ömürbek ve Eren, 2016:59). Tablo 7 'de ortak görüş sütununda bulunan ondalıklı sayılar bu şekilde hesaplanmıştır. 
Tablo 7. Kriterlerin İkili Karşılaştırmalarına İlişkin Ortak Görüş

\begin{tabular}{|c|c|c|c|c|c|c|c|c|c|c|c|c|c|}
\hline Kriterler & $\begin{array}{c}\text { K.V. } \\
1\end{array}$ & $\begin{array}{c}\text { K.V. } \\
2\end{array}$ & $\begin{array}{c}\text { K.V. } \\
3\end{array}$ & $\begin{array}{c}\text { K.V. } \\
4\end{array}$ & $\begin{array}{c}\text { K.V. } \\
5\end{array}$ & $\begin{array}{c}\text { K.V. } \\
6\end{array}$ & $\begin{array}{c}\text { K.V. } \\
7\end{array}$ & $\begin{array}{c}\text { K.V. } \\
8\end{array}$ & $\begin{array}{c}\text { K.V. } \\
9\end{array}$ & $\begin{array}{c}\text { K.V. } \\
10\end{array}$ & $\begin{array}{c}\text { Geometrik } \\
\text { Ortalama }\end{array}$ & $\begin{array}{l}\text { Ortak } \\
\text { Görüş }\end{array}$ & Kriterler \\
\hline Temizlik & 1 & 3 & 1 & 3 & 1 & 7 & 9 & 5 & 7 & 5 & 3,16 & 3 & Rahatlık \\
\hline Temizlik & 5 & 1 & 3 & 6 & 1 & 3 & 9 & 3 & 5 & 1 & 2,86 & 3 & Konum \\
\hline Temizlik & 3 & 7 & 3 & 4 & 1 & 1 & 9 & 3 & 3 & 3 & 3,01 & 3 & Olanaklar \\
\hline Temizlik & 7 & 4 & 1 & 5 & 5 & 9 & 7 & 2 & 7 & 5 & 4,46 & 4 & Çalışanlar \\
\hline Temizlik & $1 / 3$ & 4 & 1 & 3 & $1 / 5$ & 7 & 9 & $1 / 3$ & 1 & 1 & 1,33 & 1 & $\begin{array}{c}\text { Fiyat/Fayda } \\
\text { Dengesi }\end{array}$ \\
\hline Temizlik & 9 & 9 & 9 & 9 & 3 & 7 & 9 & 9 & 9 & 7 & 7,67 & 8 & $\begin{array}{c}\text { Ücretsiz } \\
\text { WiFi }\end{array}$ \\
\hline Rahatlık & 5 & 1 & 1 & 2 & 1 & $1 / 7$ & $1 / 2$ & $1 / 5$ & $1 / 5$ & $1 / 3$ & 0,63 & $1 / 2$ & Konum \\
\hline Rahatlık & 1 & 6 & 5 & 1 & 1 & $1 / 3$ & 2 & 1 & $1 / 3$ & $1 / 3$ & 1,08 & 1 & Olanaklar \\
\hline Rahatlık & 5 & 1 & 1 & 5 & 1 & 3 & 1 & 1 & $1 / 7$ & $1 / 3$ & 1,14 & 1 & Çalışanlar \\
\hline Rahatlık & $1 / 3$ & 4 & 1 & 1 & $1 / 7$ & 4 & 2 & $1 / 5$ & $1 / 8$ & $1 / 5$ & 0,61 & $1 / 2$ & $\begin{array}{c}\text { Fiyat/ } \\
\text { Fayda } \\
\text { Dengesi }\end{array}$ \\
\hline Rahatlık & 8 & 7 & 9 & 9 & 1 & 7 & $1 / 3$ & 3 & $1 / 3$ & $1 / 5$ & 2,15 & 2 & $\begin{array}{c}\text { Ücretsiz } \\
\text { WiFi }\end{array}$ \\
\hline Konum & $1 / 3$ & 4 & 1 & $1 / 5$ & 1 & 1 & 2 & 3 & 1 & 1 & 1,05 & 1 & Olanaklar \\
\hline Konum & 1 & 1 & $1 / 5$ & 3 & 5 & 7 & $1 / 2$ & 1 & 3 & 3 & 1,58 & 2 & Çalışanlar \\
\hline Konum & $1 / 7$ & 1 & 1 & $1 / 5$ & $1 / 5$ & 5 & 3 & $1 / 5$ & $1 / 5$ & $1 / 3$ & 0,51 & $1 / 2$ & $\begin{array}{c}\text { Fiyat/Fayda } \\
\text { Dengesi }\end{array}$ \\
\hline Konum & 3 & 7 & 9 & 5 & 7 & 7 & $1 / 3$ & 7 & 5 & 5 & 4,40 & 4 & $\begin{array}{c}\text { Ücretsiz } \\
\text { WiFi }\end{array}$ \\
\hline Olanaklar & 5 & $1 / 2$ & 1 & 3 & 5 & 5 & 1 & 1 & 1 & 1 & 1,69 & 2 & Çalışanlar \\
\hline Olanaklar & $1 / 3$ & $1 / 4$ & $1 / 3$ & $1 / 5$ & 1 & 2 & $1 / 2$ & $1 / 3$ & $1 / 5$ & $1 / 7$ & 0,37 & $1 / 3$ & $\begin{array}{c}\text { Fiyat/Fayda } \\
\text { Dengesi }\end{array}$ \\
\hline Olanaklar & 7 & 3 & 9 & 5 & 5 & 7 & $1 / 3$ & 5 & 1 & 1 & 2,98 & 3 & $\begin{array}{c}\text { Ücretsiz } \\
\text { WiFi }\end{array}$ \\
\hline Çalışanlar & $1 / 4$ & $1 / 5$ & 1 & $1 / 6$ & $1 / 9$ & 1 & 3 & $1 / 3$ & $1 / 9$ & $1 / 5$ & 0,34 & $1 / 3$ & $\begin{array}{c}\text { Fiyat/Fayda } \\
\text { Dengesi }\end{array}$ \\
\hline Çalışanlar & 3 & 4 & 9 & 3 & 1 & 1 & $1 / 3$ & 6 & 1 & 1 & 1,91 & 2 & $\begin{array}{c}\text { Ücretsiz } \\
\text { WiFi }\end{array}$ \\
\hline $\begin{array}{c}\text { Fiyat/Fayda } \\
\text { Dengesi }\end{array}$ & 7 & 6 & 9 & 9 & 9 & 3 & $1 / 3$ & 6 & 9 & 9 & 5,22 & 5 & $\begin{array}{c}\text { Ücretsiz } \\
\text { WiFi }\end{array}$ \\
\hline Tutarlılık & 0,055 & 0,095 & 0,077 & 0,085 & 0,082 & 0,090 & 0,070 & 0,076 & 0,079 & 0,082 & - & 0,01335 & \\
\hline
\end{tabular}

Karmaşık bir karar problemi genellikle nicel ve nitel kriterleri kapsadığından ikili karşılaştırmalardan elde edilen yargılar sübjektifdir. Bununla birlikte insanın doğası gereği yapılan ikili karşılaştırmalar tutarlı olmayabilmektedir. Böylelikle karşılaştırmalarda oluşabilecek tutarsızlıklar, alternatiflere ilişkin sıralama tercihlerinde öncelik değerlerinin tutarsız olmasını sağlayabilir. Genellikle tutarsızlık oranının \% 10 ve daha aşağı olması kabul edilebilir bulunmaktadır. Bu oranın " 0 " olması durumunda karar vericilerin yargılarında tamamiyle tutarlı olduğu söylenebilir (Göral, 2015:12).

AHP yönteminde değerlendirmeler yapılırken ikili karşılaştırmaların tutarlılık testi kontrol edilmektedir. Tutarlılığı sağlamaması durumunda karar vericilerden kararlarını tekrar gözden geçirerek düzeltmesi istenmektedir (Ömürbek ve Eren, 2016:52). Tablo 7'de yer alan karar vericilerden K.V. 1, K.V. 2 ve K.V. 10'nun ilk anket verileri değerlendirildiğinde tutarsızlık oranlarının 0,10'nun üzerinde olduğu belirlenmiştir. Bu sebeple karar vericiler ile tekrar görüşülerek kararlarının tekrar gözden geçirilmesi istenmiştir. Böylelikle tüm karar vericilerin tutarlılığı sağlanmıştır. Karar vericilerin geometrik ortalamaları saptanarak belirlenen ortak görüş sütunundaki ikili karşılaştırma yargılarının tutarsızlık değeri “ $0,01335<0,10$ ” şeklinde hesaplanmıştır. Değerlendirmelerde elde edilen bulgulara göre ikili karşılaştırmaların tutarlı olduğu saptanmıştır. Bu sonuçlara göre kriterlerin ağırlık değerleri Tablo 8'de gösterilmektedir. 
Tablo 8. Otel Tercihinin Belirlenmesinde Kriterlerin Ağırlık Değerleri

\begin{tabular}{|l|c|}
\hline Kriterler & Ağırlıklar \\
\hline Temizlik & 0,30496 \\
\hline Rahatlık & 0,09083 \\
\hline Konum & 0,13449 \\
\hline Olanaklar & 0,11041 \\
\hline Çalışanlar & 0,07371 \\
\hline Fiyat/Fayda Dengesi & 0,24630 \\
\hline Ücretsiz WiFi & 0,03930 \\
\hline
\end{tabular}

Tablo 8'e göre çalışmada AHP yöntemi aşamalarıyla ikili karşılaştırmalar sonucu elde edilen özvektör değeri en yüksek olan kriter 0,30496 değeriyle Temizlik kriteri olarak belirlenmiştir. Bu kriteri sırasıyla 0,24630 özvektör değeriyle Fiyat/Fayda Dengesi, 0,13449 özvektör değeriyle Konum, 0,11041 özvektör değeriyle Olanaklar, 0,09083 özvektör değeriyle Rahatlık, 0,07371 özvektör değeriyle Çalışanlar ve 0,03930 özvektör değeriyle Ücretsiz WiFi kriterleri izlemiştir. Çalışmada belirlenen ağırlık değerleri bir sonraki adım olan PROMETHEE hesaplamalarında kullanılmıştır.

\section{PROMETHEE Modeli Veri Matrisinin Oluşturulması}

Çalışmada analiz edilen kriterlere ilişkin bilgiler ve ağırlık değerleri Şekil 2' de gösterilmektedir. $\mathrm{Bu}$ aşamada PROMETHEE tekniğinin uygulamasında "Visual PROMETHEE" programı kullanılmıştır. Şekil 2' deki PROMETHEE tablosu, programın ekran görüntüsü şeklindedir.

\begin{tabular}{|c|c|c|c|c|c|c|c|c|}
\hline & & $\square$ & 曰 & V & $\nabla$ & $\nabla$ & $\nabla$ & $\nabla$ \\
\hline & PROMETHEE TABLO & Temizlik & Rahatlik & Konum & Olanaklar & Çalışanlar & Fiyat/Fayda ... & Üretsiz WiFi \\
\hline & Unit & puan & puan & puan & puan & puan & puan & puan \\
\hline & Cluster/Group & & & & & & & \\
\hline & Preferences & & & & & & & \\
\hline & Min/Max & $\max$ & $\max$ & $\max$ & $\max$ & $\max$ & $\max$ & $\max$ \\
\hline & Weight & 0,30 & 0,09 & 0,13 & 0,11 & 0,07 & 0,25 & 0,04 \\
\hline & Preference Fn, & Linear & Linear & Linear & Linear & Linear & Linear & Linear \\
\hline & Thresholds & absolute & absolute & absolute & absolute & absolute & absolute & absolute \\
\hline & -Q: Indifference & 0,42 & 0,50 & 0,24 & 0,44 & 0,31 & 1,00 & 0,39 \\
\hline & -P: Preference & 1,07 & 1,18 & 0,60 & 1,14 & 0,80 & 0,95 & 0,94 \\
\hline & -S: Gaussian & $n / a$ & $\mathrm{n} / \mathrm{a}$ & $\mathrm{n} / \mathrm{a}$ & $\mathrm{n} / \mathrm{a}$ & $n / a$ & $\mathrm{n} / \mathrm{a}$ & $\mathrm{n} / \mathrm{a}$ \\
\hline & Statistics & & & & & & & \\
\hline & Minimum & 8,10 & 8,00 & 9,10 & 7,70 & 8,30 & 7,70 & 7,50 \\
\hline & Maximum & 9,50 & 9,50 & 9,90 & 9,20 & 9,60 & 9,20 & 8,90 \\
\hline & Average & 8,71 & 8,61 & 9,50 & 8,44 & 8,96 & 8,37 & 8,41 \\
\hline & Standard Dev. & 0,51 & 0,55 & 0,28 & 0,54 & 0,38 & 0,45 & 0,44 \\
\hline & Evaluations & & & & & & & \\
\hline$\square$ & Otel 1 & 8,70 & 8,50 & 9,70 & 8,30 & 9,00 & 8,50 & 8,80 \\
\hline$\nabla$ & Otel 2 & 8,50 & 8,40 & 9,70 & 8,30 & 9,20 & 8,50 & 8,40 \\
\hline$\square$ & Otel 3 & 8,60 & 8,40 & 9,50 & 8,50 & 8,70 & 8,40 & 8,40 \\
\hline 口 & Otel 4 & 8,10 & 8,00 & 9,10 & 7,70 & 8,30 & 7,90 & 8,20 \\
\hline$\square$ & Otel 5 & 9,50 & 9,50 & 9,90 & 9,20 & 9,60 & 9,20 & 8,90 \\
\hline$\nabla$ & Otel 6 & 8,20 & 8,10 & 9,50 & 7,90 & 8,80 & 7,70 & 7,50 \\
\hline$\square$ & Otel 7 & 9,40 & 9,40 & 9,10 & 9,20 & 9,10 & 8,40 & 8,70 \\
\hline
\end{tabular}

Şekil 2. PROMETHEE Modelinin Veri Matrisi 
Şekil 2'ye göre, matrisin soldan ilk sütununda birim (unit) satırı bulunmakta ve kriterlerin ait olduğu birimi temsil etmektedir. İkinci satırda ise kriterlere ait küme (cluster) /grup simgesi yer almaktadır. Çalışmada oluşturulan PROMETHEE modelinin veri matrisi Tercihler (Preferences), İstatistikler (Statistics) ve Değerlendirmeler (Evaluations) olmak üzere üç bölümden oluşmaktadır. Matrisin sağ tarafındaki sütunlarda kriterler, sol alt bölümündeki Değerlendirmeler kısmının satırlarında ise alternatifler (Otel ${ }_{1}$ Otel $2_{2}, \ldots$, Otel 7 ) bulunmaktadır. Tercihler bölümündeki satırlar sırasıyla; kriterlerin fayda ya da maliyet yönlü veya minimizasyon ya da maksimizasyon yönlü olup olmadığının seçimine ilişkin min/max satırı, kriter ağırlık değeri (weight), tercih fonksiyonu seçimi (preference fn.), eşik değeri (thresholds), parametreler; farksızlık değeri " $q$ " (indifference), kesin tercih eşiği " $p$ " (preference) ve $q$ ve $p$ parametereleri arasındaki standart sapma ya da ara değer " $\mathrm{s}$ " (gaussian) şeklindedir. İstatistikler bölümünde alternatiflere ait ilgili kriterin en düşük ve en yüksek değerleri, kriterlere ilişkin alternatiflerin ortalama değerleri ve standart sapmaları bulunmaktadır. Değerlendirmeler bölümünde ise her bir alternatife ait kriterin ölçüm değerleri yer almaktadır.

Çalışmada birim olarak "puan" tanımlanmıştır. Bunun sebebi misafirlerin booking.com'da alternatiflere ilişkin kriterleri değerlendirmesinde 1-10 arası değerlendirme puanlarının kullanılmasıdır. Her bir kriterin değerinin yüksek olması fayda yönlü olduğundan maksimizasyon tipi seçilmiştir. Kriterlerin ağırlıklarına AHP tekniğiyle elde edilen değerler girilmiştir. Kriterlere ilişkin tüm değerlerin belirli bir ortalamanın üzerinde bir değere sahip karar seviyelerinden yana kullanılması istendiği için beşinci tip (lineer) tercih fonksiyonu kullanılmıştır. Kriterlere ilişkin değerler yüzdelik (percentage) yerine sayı değeri olduğundan mutlak (absolute) seçilmiştir. Parametrelerden $q$ ve $p$ değerleri için Visual PROMETHEE programında yer alan yardım asistanının önerdiği değerler seçilmiştir. Gaussian tercih fonksiyonu kullanılmadığından burada herhangi bir değer bulunmamaktadır.

\section{Alternatiflerin Pozitif ve Negatif Üstünlüklerinin Belirlenmesi}

$\mathrm{Bu}$ aşamada her bir alternatife ilişkin +1 ile -1 aralığında yer alan pozitif ve negatif değerler hesaplanmaktadır. Burada analizi yapılan alternatifin diğer alternatiflere göre pozitif üstünlügünü "pozitif değer" gösterirken, analizi yapılan alternatifin diğer alternatiflere göre hangi ölçüde zayıf olduğunu negatif değer göstermektedir. Çalışmada PROMETHEE tekniğiyle elde edilen her bir alternatife ilişkin pozitif üstünlükler $\left(\Phi^{+}\right)$ile negatif üstünlükler $\left(\Phi^{-}\right)$Tablo $9^{\prime}$ da sunulmaktadır.

Tablo 9. İstanbul Otelleri için Pozitif ( $\left.\Phi^{+}\right)$ve Negatif Üstünlükler ( $\Phi^{-}$)

\begin{tabular}{|c|c|c|c|c|c|c|c|}
\hline$\Phi$ & Otel $_{1}$ & Otel $_{2}$ & Otel $_{3}$ & Otel $_{4}$ & Otel $_{5}$ & Otel $_{6}$ & Otel $_{7}$ \\
\hline$\Phi^{+}(a)$ & 0,0884 & 0,0744 & 0,0482 & 0,0037 & 0,4790 & 0,0247 & 0,3425 \\
\hline$\Phi^{-}(a)$ & 0,1031 & 0,1352 & 0,1361 & 0,3553 & 0,0000 & 0,2392 & 0,0919 \\
\hline
\end{tabular}

Tablo 9' da görüldügüü üzere Otel5 alternatifi 0,4790 pozitif üstünlük değeriyle en yüksek pozitif üstünlüğe sahip alternatiftir. Ayrıca negatif üstünlük değeri sıfırdır. Bu alternatifi 0,3425 pozitif üstünlük ve 0,0919 negatif üstünlük değerleriyle Otel7 alternatifi izlemektedir. Otel ${ }_{4}$ alternatifi ise 0,0037 pozitif ve 0,3553 negatif üstünlük değerleriyle en düşük performansa sahip alternatiftir. 


\section{PROMETHEE I ile Kısmi Sıralamanın Belirlenmesi}

Pozitif ve negatif üstünlükleri belirlenen alternatiflerin PROMETHEE I ile oluşan kısmi sıralamaları Şekil 3'de gösterilmektedir.

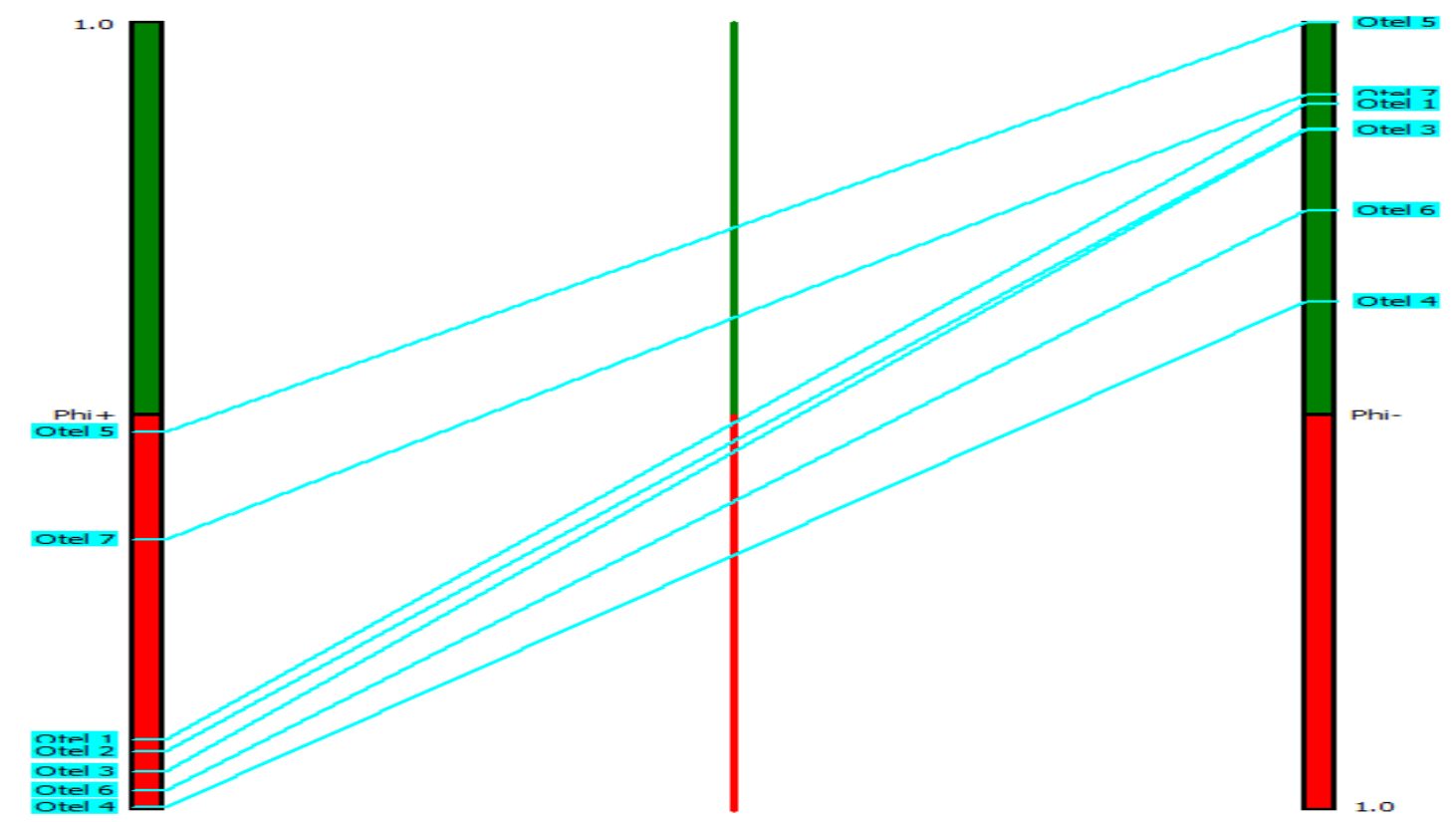

Şekil 3. PROMETHEE I Kısmi Sıralama Sonuçları

Şekil 3'de alternatif oteller için ortaya çıkan pozitif ve negatif Phi değerleri bulunmaktadır. Her bir otelin pozitif üstünlük düzeyi solda yer alan sütunda, negatif üstünlük düzeyi ise sağdaki sütunda yer almaktadır. Şekil 3'e göre, her iki sütunda üst bölgelerde bulunan otellerin diğer alternatif otellere göre daha baskın oldukları görülmektedir. Bu bilgilere göre Otel ${ }_{4}$ alternatifinin diğer hiçbir alternatife karşı üstünlüğü bulunmamaktadır. Diğer alternatif oteller çerçevesinde net bir sıralama oluşturabilmek için PROMETHEE II değerlerini incelemek gerekmektedir.

\section{PROMETHEE II ile Tam Önceliklerin Belirlenmesi}

PROMETHEE II ile alternatiflere ilişkin hem pozitif hem de negatif değerler ele alınarak net üstünlük değerleri incelenebilmektedir. PROMETHEE II sonuçları Şekil 4'de sunulmaktadır.

Şekil 4'e göre Otels alternatifi inceleme kapsamına alınan alternatif oteller içerisinde en yüksek net Phi değerine sahip alternatif olarak ilk sırada bulunmaktadır. Otels alternatifini sırasıyla Otel7, $\mathrm{Otel}_{1}, \mathrm{Otel}_{2}, \mathrm{Otel}_{3}, \mathrm{Otel}_{6}$ ve Otel ${ }_{4}$ alternatifleri takip etmiştir. Alternatif olarak belirlenen İstanbul otellerinin üstünlük sıralaması Tablo $10^{\prime}$ da sunulmuştur.

Tablo 10'daki Phi $(\Phi)$ değerleri otellerin üstünlük sıralamasını göstermektedir. Buna göre Otel 5 ve Otel 7 alternatifleri haricinde diğer alternatif oteller negatif Phi değerine sahip olmuştur. Altıncı sırada yer alan Otel 6 alternatifinin araştırma probleminde yer alan Booking.com "Popüler Seçimlerimiz" listesindeki sıralaması ile karşılaştırıldığında sıralamadaki yeri değişmeyen tek alternatif otel olduğu görülmektedir. 


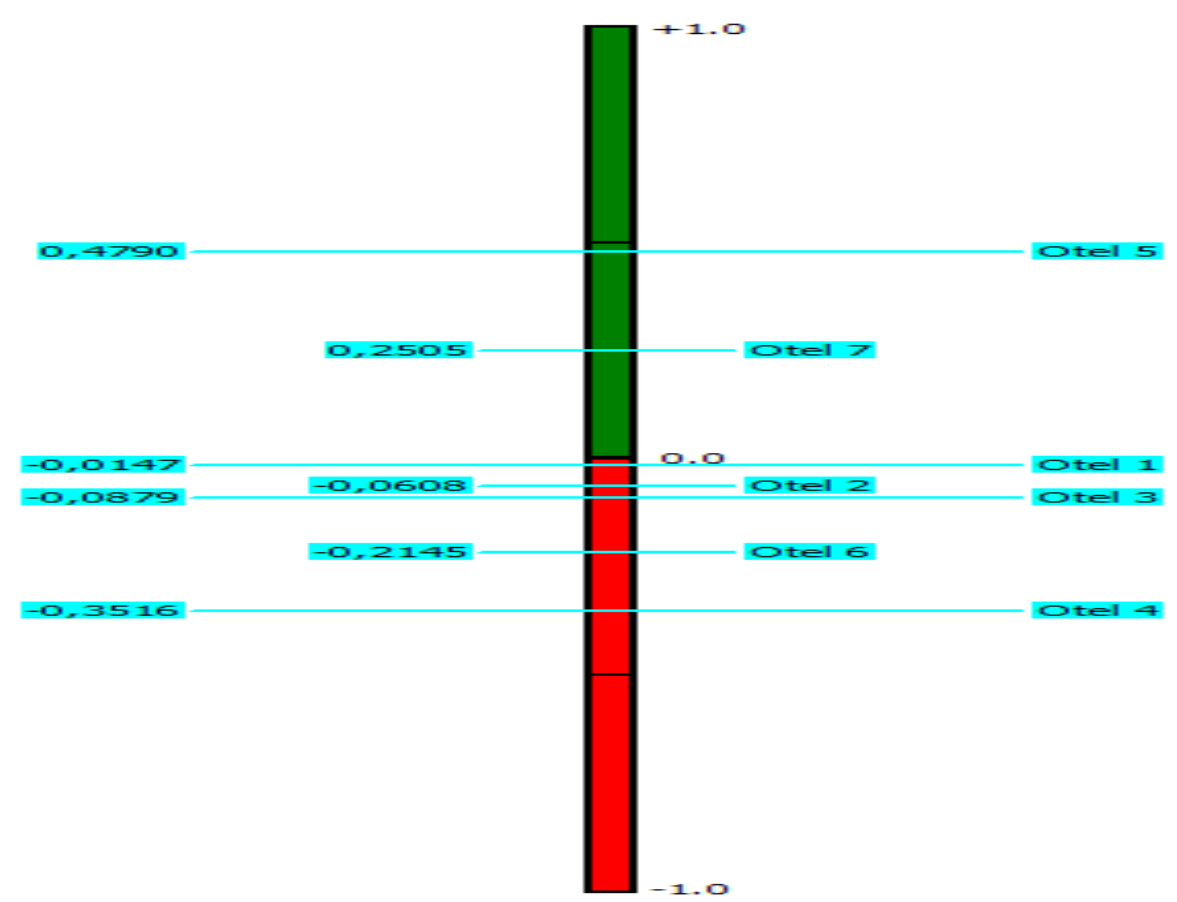

Şekil 4. PROMETHEE II Sıralama Sonuçları

Tablo 10. İstanbul Otelleri için Üstünlük Sıralaması

\begin{tabular}{ccc} 
Siralama & Otel & Phi $(\boldsymbol{\Phi})$ \\
\hline $\mathbf{1}$ & Otel 5 & 0,4790 \\
$\mathbf{2}$ & Otel 7 & 0,2505 \\
$\mathbf{3}$ & Otel 1 & $-0,0147$ \\
$\mathbf{4}$ & Otel 2 & $-0,0608$ \\
$\mathbf{5}$ & Otel 3 & $-0,0879$ \\
$\mathbf{6}$ & Otel 6 & $-0,2145$ \\
$\mathbf{7}$ & Otel 4 & $-0,3516$ \\
\hline
\end{tabular}

\section{Alternatif ve Kriterlerin GAIA Düzleminde Gösterimi}

GAIA düzlemi, karar vericiye PROMETHEE sonuçlarının basit bir biçimde sunulduğu grafik gösterimidir. Karar verici, GAIA geometrik gösterimiyle ele alınan problemde çelişen kriterlere ilişkin sonuçları bir düzlem üzerinde daha kolay ve çabuk bir biçimde inceleyerek karar verebilmektedir (Genç, 2013:134). Çok kriterli problem çözümleri için GAIA düzleminde alternatif ve kriterler iki boyutlu bir şekilde gösterilmektedir. Grafiksel gösterimde alternatifler kare nokta biçiminde, kriterler ise vektör şeklinde sunulmaktadır (Uygurtürk ve Korkmaz, 2015:150). İstanbul otellerinin ve değerlendirmede kullanılan kriterlerin bulunduğu GAIA düzlemi Şekil 5'de sunulmaktadır.

Şekil 5'de pozitif üstünlüğe sahip alternatifler GAIA grafiğinin sağ bölümünde, negatif üstünlüğe sahip alternatifler ise sol bölümünde bulunmaktadır. Kırmızı kalın çizgi (optimal karar çubuğu) en uygun olan alternatifleri karar vericiye göstermektedir. Karar çubuğuna yakın olan değerler, analiz edilen kriterler kapsamında tercih edilmesi gereken otelleri belirtmektedir. İnce çubuklarla belirtilen kriterlere yakın oteller analiz edilen kriter için öncelikle tercih edilmesi gereken otelleri belirtmektedir. GAIA düzleminde kriterleri gösteren ince çubukların uzunluğu ilgili kriterin 
ayrıştırıcı özelliğini ve karar çubuğunu etkilemedeki önemini göstermektedir. Kriter çubuğu ne kadar kısa ise ilgili kriterin ayrıştırma gücünün düşük olduğu anlaşılmaktadır. Bunun nedeni ayrıştırma gücü zayıf olan kriterlerin GAIA düzleminde daha dik pozisyonda olmasından ve böylelikle grafik gösteriminde kısa görünmesinden kaynaklanmaktadır (Genç, 2013:152). Şekil 5 'te en uzun kriter çubuğu Konum kriterine, en kısa olan ise Fiyat/Fayda Dengesi kriterine aittir. Buna göre ayrıştırıcı gücü en yüksek kriterin konum, en düşük kriterin ise fiyat/fayda dengesi kriteri olduğu görülmektedir. Başka bir ifadeyle Şekil 2'deki kriterlere ait misafir değerlendirme puanları arasında en yüksek ortalama değere sahip olan kriter Konum kriteri, en düşük ortalama değere sahip olan kriter ise Fiyat/Fayda Dengesi kriteridir. GAIA grafiğinde Otels alternatifi optimal karar çubuğu yönünde bulunmaktadır. Ayrıca bu durumun PROMETHEE II sonuçlarıyla tutarlı olduğu görülmektedir. Bununla birlikte analizin ölçüm kalitesi Şekil 5'in sağ alt tarafında belirtildiği üzere \%89'dur. Bu değerin \%70'in üzerinde olduğu durumlarda sağlıklı sonuçların elde edildiğine karar verilebilmektedir (Karahan ve Peşmen, 2020:282). Buna göre, yapılan analizde otellerin tercih sıralamasına ilişkin hesaplanan performanslarının ölçüm kalitesinin çok iyi düzeyde olduğuna karar verilebilir.

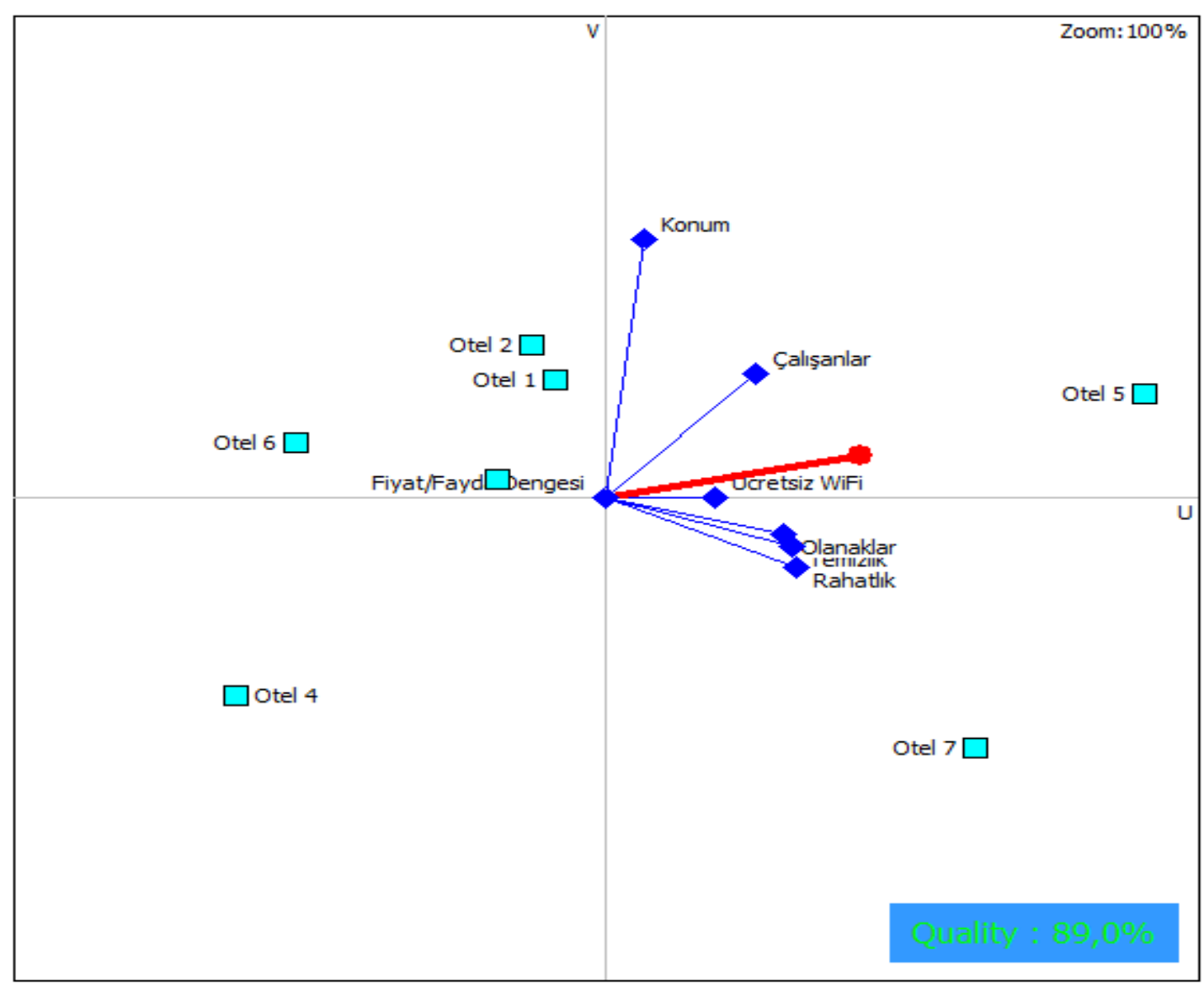

Şekil 5. GAIA Düzlemi 


\section{Kriterlerin Alternatifleri Etkileme Düzeyleri ve Yönleri}

Visual PROMETHEE programında PROMETHEE II sonuçlarına göre kriterlerin alternatifleri etkileme düzeyleri ve yönleri grafiksel olarak gösterilebilmektedir. Şekil 6'da çalışma kapsamında analiz edilen kriterlerin alternatifleri etkileme düzeyleri ve yönleri sunulmaktadır.
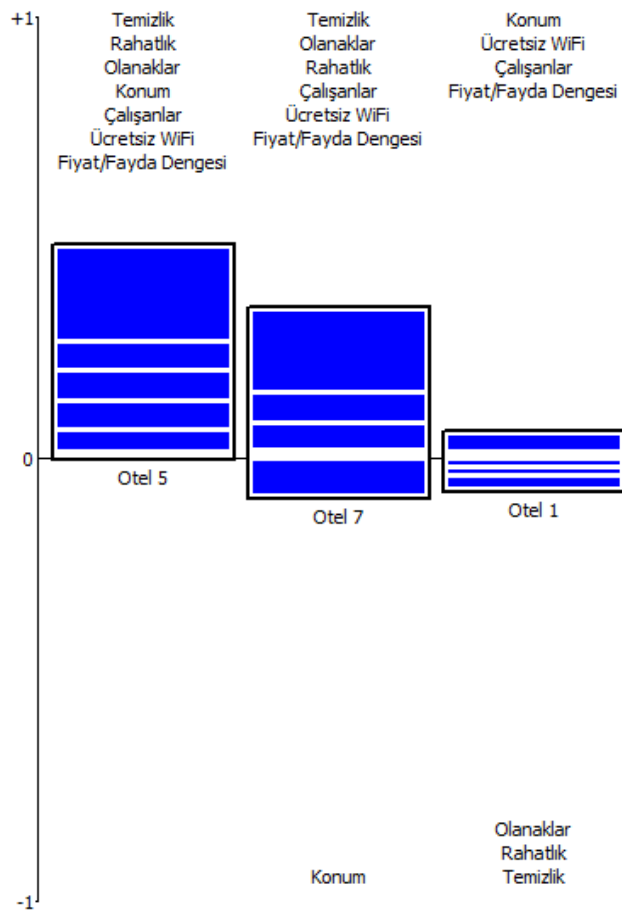

Konum

Çalş̧anlar
Fiyat/Fayda Dengesi

Ücretsiz WiFi

Ücretsiz WiF

Ucretsiz WiF
Olanaklar

Fiyat/Fayda Dengesi

t/Fayda Dengesi Fiyat/Fayda Dengesi

Konum

Fiyat/Fayda Dengesi
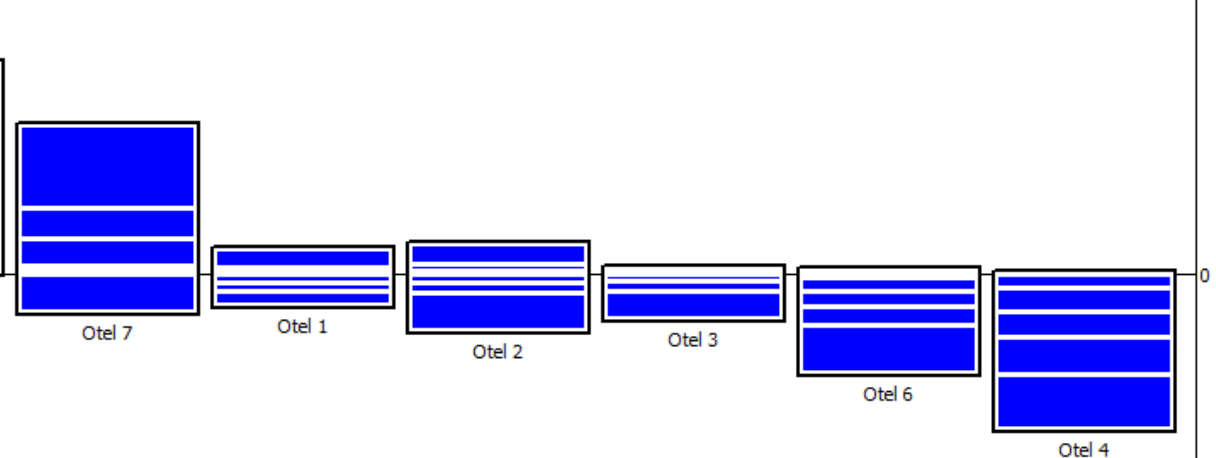

Şekil 6. Kriterlerin Alternatifleri Etkileme Düzeyleri ve Yönleri

Şekil 6'da çalışmada yer alan her bir alternatif, analiz edilen kriter sayısı kadar dilimlere ayrilmıştır. Burada PROMETHEE II ile elde edilen net değerlerin dilimlere ayrılmış hali gösterilmektedir. Alternatiflerin içinde yer alan her bir dilimde, alternatife ait net Phi değerine katkı sağlayan her bir kriterin kriter ağırlığı da dikkate alınmış biçimde katkısı görülmektedir. Buna göre bir alternatifin net Phi skoru, pozitif dilimlerin toplamının negatif dilimlerin toplamından çıkarıldığında elde edilen değere eşit olmaktadır.

Şekil 6'ya göre, Otel 5 alternatifinin Phi değerine tüm kriterler pozitif katkı sağlarken en büyük katkıyı Temizlik kriteri sağlamıştır. PROMETHEE II tam sıralama sonuçlarına göre ikinci sırada yer alan Otel 7 alternatifinin Phi değerine Konum kriteri negatif etki sağlarken diğer kriterler pozitif katkı sağlamıştır. Otel7 alternatifine en yüksek pozitif katkıyı Otels kriterinde olduğu gibi Temizlik kriterinin sağladığı görülmektedir. Sıralamada üçüncü olan Otel ${ }_{1}$ alternatifi incelediğinde, Konum, Ücretsiz WiFi, Çalışanlar ve Fiyat/Fayda Dengesi kriterlerinin ilgili alternatifin Phi değerine pozitif katkı yaparken, diğer kriterler negatif etki sağlamıştır. Otel alternatifinde, sonraki sıralamalarda yer alan alternatiflerde olduğu gibi negatif etki yapan kriterlerin değerleri pozitif katkı sağlayan kriterlerin değerinden yüksek olduğundan dolayı Phi değeri negatiftir. Otelı alternatifine en yüksek katkıyı Konum kriteri sağlamıştır. Dördüncü sırada yer alan Otel2 alternatifine Konum kriteri en yüksek pozitif katkıyı yaparken bu kriteri Çalışanlar, Ücretsiz WiFi ve Fiyat/Fayda Dengesi kriterleri izlemiştir. Diğer kriterler ise negatif etki sağlarken en yüksek negatif etkiyi Temizlik kriteri yapmıştır. Beşinci sırada bulunan Otels alternatifine negatif etki sağlayan kriterler Çalışanlar, Rahatlık ve Temizlik olmuştur. Bunların içinde en yüksek 
değerde negatif etki sağlayan kriter Temizlik kriteridir. Diğer kriterler ise düşük düzeyde pozitif katkı sağlamıştır. Altıncı sırada yer alan Otel6 alternatifinin Phi değerine Konum ve Fiyat/Fayda Dengesi düşük düzeyde pozitif katkı sağlarken diğer kriterler negatif etki yapmıştır. Otel6 alternatifine en yüksek negatif etki sağlayan kriter ise Temizlik kriteri olmuştur. Son olarak yedinci sırada yer alan Otel 4 alternatifinin Phi değerine Fiyat/Fayda Dengesi kriteri düşük düzeyde pozitif katkı sağlarken diğer kriterler negatif etki yapmıştır. Otel ${ }_{4}$ alternatifine ilişkin kriterler içinden en yüksek düzeyde negatif etki sağlayan kriter ise Temizlik kriteri olmuştur.

\section{TARTIŞMA, SONUÇ ve ÖNERILLER}

Turistlerin tatil kararı vermelerinde gelişen internet teknolojileriyle birlikte turist deneyimlerinin önemi artmıştır. Burada potansiyel turistlerin geçmiş turist deneyimlerine internet ile erişimlerinin hız kazanması büyük bir etkendir. Bu çalışmada yapılan internet sitelerinin içerik analizi ve literatür incelemesinde turistlerin \%90'ının tatil aramaları için çevrimiçi internet sitelerini ve mobil uygulamalarını kullandıkları görülmektedir. Yapılan çalışmalar ortalama olarak bir tatil kararı vermede turistlerin üç ay öncesinden internetten araştırmalara başladığını göstermektedir. Turistlerin rezervasyonlarını çevrimiçi yapma oranı ise $\% 80$ seviyelerindedir. İnternet üzerinden gerçekleşen rezervasyonların önemli bir kısmı sıralama listelerinde üst sıralarda bulunan işletmelerde yoğunlaşmaktadır. Bu doğrultuda konaklama tesisleri ilgili sıralamalarda rakipleriyle yoğun bir rekabet içerisine girmektedirler. Bununla birlikte olumlu misafir deneyimleri turizm işletmelerini TripAdvisor, HolidayCheck gibi popüler sıralamalarda üst sıralara taşırken olumsuz yorumlar ise bunun tersine işletmelerin alt sıralarda yer almasını sağlamaktadır. Turist deneyimlerinin popüler deneyim paylaşım platformu olan internet sitelerindeki sıralamalara etkisinin yanında aynı şekilde çevrimiçi seyahat acentelerinin kendi sıralama listelerinde de etkili olduğu görülmektedir. Turizmde lider deneyim paylaşım platformları ve çevrimiçi seyahat acenteleri günden güne sıralama listelerindeki bu rekabeti güçlendiren uygulamalar geliştirmektedirler. Sıralama listelerine yönelik dinamik stratejiler geliştiren Booking.com çevrimiçi seyahat acentesi turizmde bu uygulamaları sunan öncü geliştiricilerin başındadır.

Bu çalışmada Booking.com internet sitesindeki İstanbul ili "Popüler Seçimlerimiz" otel sıralama listesinde yer alan ilk 7 otel araştırmada değerlendirilmeye alınmıştır. Değerlendirmeye alınan otellerin Booking.com internet sitesindeki misafir görüşleri bölümünde bulunan ve otel sıralamalarında etkisi bulunmayan 7 alt değerlendirme kriteri kullanılmıştır. Böylelikle Booking.com popüler seçimlerimiz sıralaması ile alt kriter puanları kullanılarak oluşan sıralama arasında etkin bir kıyaslama yapıldığı söylenebilir. Buna göre araştırma kapsamında ilk olarak AHP yöntemi ile kriter ağırlıklarının hesaplanması Super Decisions programı kullanılarak yapılmıştır. Bunun için turizmde dijital pazarlama yetkililerinden on kişiden oluşan uzman görüşleri Saaty'nin 1-9 ölçeğine göre geliştirilen anket ile elde edilerek kriter ağırlıkları belirlenmiştir. Ortaya çıkan bulgulara göre kriter ağırlıkları sırasıyla Temizlik $(0,30496)$, Fiyat/Fayda Dengesi (0,24630), Konum (0,13449), Olanaklar $(0,11041)$, Rahatlık $(0,09083)$, Çalışanlar $(0,07371)$ ve Ücretsiz WiFi $(0,03930)$ şeklindedir. Daha önce yapılan benzer araştırmalar incelendiğinde, Göral'ın 2015 yılında TripAdvisor kriterlerini baz alarak öğretim elemanlarının otel tercihine ilişkin yaptığı araştırmasında ortaya çıkan kriter ağırlıkları sırasıyla; Fiyat/Fayda Dengesi $(0,24788)$, Uyku Kalitesi $(0,24411)$, Temizlik $(0,23559)$, Hizmet $(0,12482)$, Konum $(0,07862)$ ve Odalar $(0,06897)$ şeklindedir. İlgili araştırmada ilk üç kriterin ağırlı̆̆ının birbirine yakın olduğu ve en önemli kriterin Fiyat/Fayda Dengesi olduğu görülmektedir. Bu sonuç ayrıca TripAdvisor'ın kullanıcıları arasında 2016 yılında gerçekleştirdiği geniş katılımlı araştırmasında ortaya çıkan otel tercihinde turistlerin en önemli tercih kriterinin "Fiyat" olduğu 
sonucuyla da tutarlıdır (Ateş ve Yurtlu, 2019:215). Bu araştırma neticesinde fiyat kriterinin ikinci sırada yer alarak en önemli kriterin 0,30496 'lık ağırlık oranıyla Temizlik kriteri olmasının nedeni ise 2019 yılı sonunda dünyayı etkisine almaya başlayan ve 2020 yılı Mart ayında dünya geneline yayılan Covid-19 salgınının bir sonucu olduğu ile açıklanabilir.

Çalışma analizinin ikinci bölümünde, belirlenen kriter ağırlıklarına göre Visual PROMETHEE programı kullanılarak veri matrisi oluşturulmuştur. PROMETHEE II tam sıralama ile alternatif olarak belirlenen otellerin kriter ağırlıkları da hesaplamaya dahil edilerek tercih sıralaması belirlenmiştir. Çalışmanın analiz ölçüm kalitesi \%89'dur ve bu doğrultuda analize ilişkin otel tercih sıralamasında hesaplanan performansların ölçüm kalitesinin çok iyi düzeyde olduğuna karar verilebilir. Buna göre 0,4790 net üstünlük değeriyle Otels en uygun alternatif otel tercihi olarak tespit edilmiştir. Otel 5 ' i sırasıyla Otel, ${ }_{7} \mathrm{Otel}_{1}, \mathrm{Otel}_{2}, \mathrm{Otel}_{3}$, Otel 6 ve Otel ${ }_{4}$ alternatifleri takip etmiştir. Booking.com misafir görüşlerinden elde edilen alt kriter puanlarına ilişkin sıralamada sadece Otel 6 alternatifinin sıralamadaki yerinin değişmediği görülmektedir. Diğer alternatiflerin sıralamadaki yerinin değişmesine ilişkin olarak booking.com'un sıralamalara etki eden birçok dinamik faktörü birlikte uygulamasından kaynaklandığı sonucuna ulaşılmıştır. Bu faktörler çalışmanın "Booking.com Tesis Görünürlükleri” bölümünde ve Tablo 1'de sunulmaktadır.

Çalışmada elde edilen veriler ışığında konaklama tesislerine booking.com‘da görünürlüklerini arttırarak daha üst sıralarda yer alabilmelerine yönelik aşağıdaki bazı öneriler geliştirilmiştir.

- Tesis içeriklerinde yer alan fotoğrafların çözünürlüğü yüksek olmalıdır. Fotoğraflar tesisi gerçekçi bir biçimde sunmalı ve tesisin en iyi özelliklerini öne çıkarabilmelidir. İçerik bilgilerinde bulunan özellikler, oda bilgileri, açıklamalar ve board tipleri gibi bilgilerin tam ve eksiksiz olması gerekmektedir.

- Tesisin diğer tüm satış kanallarındaki en düşük fiyatlarına kıyasla Booking.com satış fiyatlarının yüksek olmamasına özen gösterilmelidir. Buna bağlı olarak tüm çevrimiçi kanallarda eşit fiyat uygulanması sağlanmalıdır. Bunun etkin sağlanabilmesi için Booking.com ile entegrasyona sahip bir kanal yöneticisi kullanılması tavsiye edilir. Ayrıca kanal yöneticisi kullanarak oda fiyatlandırmalarında dinamik fiyatlandırmalar yapılarak satış fiyatlarında getiri yönetimi politikası oluşturulabilir.

- Misafir değerlendirmeleri dinamik bir biçimde takip edilmeli ve misafirlerin gözünden tesisin güçlü ve zayıf yönleri ile tehdit ve fırsatları belirlenmelidir. Olumlu ve olumsuz tüm misafir değerlendirmeleri hassasiyetle cevaplandırılmalıdır. Olumsuz yorumların tesis için aslında bir fırsat olduğu değerlendirilmelidir.

- Tesis oda fiyatı potansiyel misafirler için çekici bir araçtır. Tesis ortalama günlük oda fiyatı (ADR) tesisin bulunduğu pazarın ortalamasına yakın bir değerde olmalıdır. Bunun için rakip tesislerin fiyatları etkin bir şekilde takip edilmeli ve uygun dönemlerde rekabete dayalı fiyatlandırmalar dinamik fiyatlandırma modeli de dikkate alınarak yapılmalıdır. Ayrıca tesisler turistlerin son dakika seyahat aramalarının artış göstermesine ilişkin olarak dinamik fiyatlandırmalarda doluluklarına göre son dakika indirimleri uygulayarak satışlarını arttırabilirler.

- İptalleri en aza indirgemek için iptal poliçelerinde esnek modeller belirlenerek çeşitlendirilmelidir. Daha esnek olmayan iptal koşullarına sahip rezervasyon tipleri (Non-Refundable: İadesi mümkün olmayan indirimli rezervasyon gibi) ile rezervasyon seçenekleri çeşitlendirilmelidir. Ayrıca dağıtım kanallarında eşit fiyat anlayışında olduğu gibi diğer satış kanallarında da aynı iptal koşulları uygulanmalıdır.

- Tesisler booking.com'da yer alan Genius ve Tercihli Ortak Programlarına dahil olarak daha fazla görünürlük elde etme konusunda fırsatlar yakalamaktadır. Bu doğrultuda 
daha fazla görünürlük elde ederek daha üst sıralarda yer almada tesislere bu programlara katılmaları önerilir.

- Çevrimiçi Seyahat Rezervasyon İstatistikleri 2020 raporuna göre, Y kuşağının \%52'sinin tatile çıkmadan önce gidecekleri otellerin web sitelerini incelediği sonucu ışı̆̆ında tesislerin yukarıda sıralanan önerileri mobil platformlar dahil kendi web sitelerinde de uygulamaları önerilir.

Booking.com üzerinde tesis sayfasını ziyaret eden potansiyel misafir sayısının rezervasyonlarını gerçekleştirme oranı bu yukarıda sayılan önerilerin uygulanmasına bağlı olarak artabilecektir. Böylelikle tesisler rezervasyon dönüşüm oranını arttırarak görünürlüklerini yükseltebilirler. Ayrıca bu önerileri çevrimiçi diğer satış kanallarında uygulamaları da diğer platformlarda görünürlüklerini ve satışlarını arttırmada fayda sağlayacaktır.

Yukarıdaki bilgiler ışığında çalışma kapsamında incelenen alternatif otellerin sıralamalarının farklılaşmasının nedeni olarak booking.com'un otel sıralamalarında uyguladığı dinamik faktörler olduğu sonucuna ulaşılmıştır. Alternatif olarak belirlenen otellerin tümünün tercihli ortak programına dahil olan tesisler olması bu işletmelerin yukarıda sunulan önerilerin genelini uyguladığını göstermektedir. Bu noktada misafir genel değerlendirme puanlarının ve rezervasyon dönüşüm oranlarının farklılık göstermesinin sıralamalara etki ettiğinden söz edilebilir. Ayrıca alternatifler içerisinde "Görünürlük Arttırıı”"yı kullanarak komisyon oranlarını $\% 20$ ila \% 50 arasında yükselten işletmelerin olabileceğini söylemek de mümkündür. Bunun için gelecek araştırmalarda tesislerin daha üst sıralarda yer almak için uyguladıkları satış stratejilerini belirleyebilmek amacıyla tesis yetkilileriyle nitel desene sahip araştırmaların gerçekleştirilmesi önerilir. Araştırma zaman kısıtı yönünden sadece İstanbul ilinde Booking.com çevrimiçi seyahat acentesinden örneklem ele alınarak analiz edilmiştir. Araştırma yönteminde AHP tekniği ile kriter ağırlıklandırması ve PROMETHEE tekniğiyle alternatif sıralaması yapılmıştır. Benzer amaçla farklı bölgelerdeki tesisleri ve çevrimiçi seyahat acentelerini farklı ÇKKV yöntemleriyle analiz eden araştırmaların gerçekleştirilmesi önerilir.

\section{KAYNAKÇA}

Adıgüzel, O., Çetintürk, İ. ve Er, O. (2009). Konaklama İşletmelerine Olan Müşteri Tercihinin Analitik Hiyerarşi Prosesi Yöntemi İle Belirlenmesi. Süleyman Demirel Üniversitesi Vizyoner Dergisi(1), 17-35.

Akincilar, A. and Dagdeviren, M. (2014). A Hybrid Multi-Criteria Decision Making Model to Evaluate Hotel Websites. International Journal of Hospitality Management (36), 263-271.

Ateş, A. ve Yurtlu, M. (2019). Online Kanal Yöneticisiyle Otel Oda Fiyatlandırmada Verim Yönetimi. Seyahat ve Otel İşletmeciliği Dergisi, 16(2), 207-228.

Aydın, U. (2007). Yöneylem Araştırması, İşletmecilik Uygulamalı Bilgisayar Destekli Modelleme. Ankara: Siyasal Kitabevi.

Booking. (2021a). Booking.com hakkında. Booking. [Online] https://www.booking.com/content/about.tr.html?label [Erişim Tarihi: 16.03.2021].

Booking. (2021b). Konuk Değerlendirmeleri Hakkında Bilmeniz Gereken Her Şey. Booking.com Partner Hub. [Online] https://partner.booking.com/tr/yard\%C4\%B1m/konukde\%C4\%9Ferlendirmeleri/genel/konuk-de\%C4\%9Ferlendirmeleri-hakk\%C4\%B1nda-bilmenizgereken-her-\%C5\%9Fey [Erişim Tarihi: 18.03.2021]. 
Booking. (2021c). Görünürlük Paneli nedir? Booking.com Partner Hub. [Online] https://partner.booking.com/tr/yard\%C4\%B1m/i\%C5\%9Finizi-

b\%C3\%BCy\%C3\%BCtmek/analizler-raporlar/g\%C3\%B6r\%C3\%BCn\%C3\%BCrl\%C3\%BCkpaneli-nedir [Erişim Tarihi: 21.03.2021]

Booking. (2021d). Görünürlük Artırıcı Hakkında Bilmeniz Gereken Her Şey. Booking.com Partner Hub. [Online] https://partner.booking.com/tr/yard\%C4\%B1m/i\%C5\%9Finizib\%C3\%BCy\%C3\%BCtmek/gelir-artisi/g\%C3\%B6r\%C3\%BCn\%C3\%BCrl\%C3\%BCk-

art\%C4\%B1r\%C4\%B1c\%C4\%B1-hakk\%C4\%B1nda-bilmeniz-gereken-her-\%C5\%9Fey [Erişim Tarihi: 21.03.2021].

Booking. (2021e). Stralama, Arama Sonuçları ve Görünürlük Hakkında Tüm Bilmeniz Gerekenler. Booking.com Partner Hub. [Online] https://partner.booking.com/tr/yard\%C4\%B1m/i\%C5\%9Finizi-

$\mathrm{b} \% \mathrm{C} 3 \% \mathrm{BCy} \% \mathrm{C} 3 \% \mathrm{BC}$ tmek/analizler-raporlar/s\%C4\%B1ralama-aramasonu\%C3\%A7lar\%C4\%B1-ve-g\%C3\%B6r\%C3\%BCn\%C3\%BCrl\%C3\%BCk-hakk\%C4\%B1ndat\%C3\%BCm [Erişim Tarihi: 21.03.2021].

Brans, J. P. and Mareschal, B. (2005). Multiple Criteria Decision Analysis-State of the Art Surveys. Boston: Springer Science Business Media Inc.

Brans, J. P. and Vincke, P. (1985). A Preference Ranking Organisation Method: The PROMETHEE Method for Multiple Criteria Decision-Making. Management Science,, 31(6), 647-656.

Condor Ferries. (2021). Online Travel Bookings Statistics 2020. Condor Ferries. [Online] https://www.condorferries.co.uk/online-travel-booking-statistics [Erişim Tarihi: 15.03.2021].

Çaylak, M. (2019). TOPSIS Yöntemi ile En Uygun Otel Seçimi. Burdur Mehmet Akif Ersoy Üniversitesi Oğuzhan Sosyal Bilimler Dergisi, 1(2), 65-76.

Çelik, P. ve Ustasüleyman, T. (2014). ELECTRE I ve PROMETHEE Yöntemleriyle GSM Operatörlerinin Hizmet Kalitesinin Değerlendirilmesi. Uluslararası İktisadi ve İdari İncelemeler Dergisi, 6(12), 137-160.

Dinçer, S. E., Ekin, T. E. ve Karakaş, K. S. (2017). Promethee Yöntemiyle Uçak Komponentlerinin Önceliklendirilmesi Problemlerine Çözüm Yaklaşımı. Social Sciences Research Journal, 6(3), 106125.

Doğan, M. F. (2021). Booking.com Rezervasyonların Arttırmanın İpuçları. Haber Turizm. [Online] https://www.haberturizm.com/booking-com-dan-daha-cok-rezervasyon-alabilirsiniz/26013/ [Erişim Tarihi: 12.04.2021].

Doğan, N. ve Gencan, S. (2013). Seyahat Acentası Yöneticilerinin Bakış Açısıyla En Uygun Otel Seçimi: Bir Analitik Hiyerarşi Prosesi (AHP) Uygulaması. Erciyes Üniversitesi İ̈BF Dergisi(41), 6988.

Gedik, Y. (2021). E-Ticaret: Teorik Bir Çerçeve. Ankara Üniversitesi Sosyal Bilimler Dergisi, 12(1), 184-198.

Genç, T. (2013). PROMETHEE Yöntemi ve GAIA Düzlemi. Afyon Kocatepe Üniversitesi İiBF Dergisi, $X V(\mathrm{I}), 133-154$.

Gökdemir, S. ve Eren, D. (2020). Turist Rehberi Seçiminin Analitik Hiyerarşi Süreci ile belirlenmesi: Tripadvisor Örneği. Journal of Tourism and Gastronomy Studies, 8(2), 1510-1526.

Göral, R. (2015). E-WOM'a Dayalı Çok Kriterli Karar Verme Teknikleri ile En Uygun Otelin Belirlenmesi ve Bir Uygulama. Selçuk Üniversitesi Sosyal Bilimler Enstitüsü Dergisi(33), 1-17. 
Güler, M. E. (2008). Incorporating Multi-Criteria Considerations Into Supplier Selection Problem Using Analytical Hierarchy Process: A Case Study. Journal of Yasar University, 3(12), 775-798.

Gündüz, H. ve Güler, M. E. (2015). Termal Turizm İşletmelerinde Çok Ölçütlü Karar Verme Teknikleri Kullanılarak Uygun Tedarikçinin Seçilmesi. Dokuz Eylül Üniversitesi İktisadi ve İdari Bilimler Fakültesi Dergisi, 30(1), 203-222.

Karaca, Y. (2011). Çok Kriterli Karar Verme Metotları ve Analitik Hiyerarşi Süreci İle Matematik Eğitimi Alanında Bir Uygulama. Yüksek Lisans Tezi. Bozok Üniversitesi Sosyal Bilimler Enstitüsü İşletme Anabilim Dalı.

Karahan, M. ve Peşmen, S. (2020). İllerarası Rekabet Gücünün Promethee Gaia Yöntemiyle Analizi. Erciyes Üniversitesi Sosyal Bilimler Enstitüsü Dergisi, 2, 272-287.

Lam, P. K. and Chin, K. S. (2005). Identifying And Prioritizing Critical Success Factors For Conflict Management In Collaborative New Product Development. Industrial Marketing Management, 34, 761-772.

Manap Davras, G. (2020). Akdeniz Turizm Destinasyonlarının Rekabet Gücü Açısından TOPSIS ve VIKOR Yöntemleri ile Karşılaştırılması. Journal of Tourism and Gastronomy Studies, 8(2), 14391456.

Ömürbek, N. ve Eren, H. (2016). PROMETHEE, MOORA ve COPRAS Yöntemleri ile Oran Analizi Sonuçlarının Değerlendirilmesi: Bir Uygulama. Mehmet Akif Ersoy Üniversitesi Sosyal Bilimler Enstitüsü Dergisi, 8(16), 174-187.

Saaty, T. L. (1990). How To Make A Decision: The Analytic Hierarchy Process. European Journal of Operational Research, (48), 9-26.

Saaty, T. L. and Özdemir, M. S. (2003). Why the Magic Number Seven Plus or Minus Two. Mathematical and Computer Modelling, 38, 233-244.

Sonel, E., Gür, Ş. ve Eren, T. (2019). Çok Ölçütlü Karar Verme ile Sağlık Turizminde Şehir Seçimi Ve Analizi. Uluslararası Global Turizm Araştırmaları Dergisi, 3(1), 27-39.

Statista. (2020). Online travel agent market size worldwide from 2019 to 2023. Statista. [Online] https://www.statista.com/statistics/1179020/online-travel-agent-market-size-worldwide/ [Erişim Tarihi: 15.03.2021].

Statista. (2021a). E-Commerce Worldwide - Statistics \& Facts. Statista. [Online] https://www.statista.com/topics/871/online-shopping/\#dossierSummary [Erişim Tarihi: 18.05.2021].

Statista. (2021b). Revenue of Booking Holdings worldwide from financial year 2007 to 2020. Statista. [Online] https://www.statista.com/statistics/225455/booking-holdings-total-revenue/ [Erişim Tarihi: 15.03.2021].

Summak, M. E., Sunar, H. ve Coşkuner, M. (2017). Otel Seçiminde Online Müşteri Deneyimlerine Dayalı Analitik Hiyerarşi Süreci Yönteminin Kullanılması: Booking.com Örneği. International Congress on Cultural Heritage and Tourism, Konya. 19-21 May1s. ss: 829-837.

Şimşek, A. ve Çatır, O. (2020). Moora Yöntemi ile Ürün Seçimi: Turizm Sektöründe Bir Uygulama. Elektronik Sosyal Bilimler Dergisi, 19(74), 549-563.

T.C. Kültür ve Turizm Bakanlığı. (2019). Sınır İstatistikleri 2019 Yılı Sınır Giriş-Çıkış İstatistikleri. Yatırım ve İşletmeler Genel Müdürlüğü. [Online] https://yigm.ktb.gov.tr/TR-249709/yillikbultenler.html [Erişim Tarihi: 25.03.2021]. 
Tayyar, N., Akcanlı, F., Genç, E. ve Erem, I. (2014). BİST'e Kayıtlı Bilişim ve Teknoloji Alanında Faaliyet Gösteren İşletmelerin Finansal Performanslarının Analitik Hiyerarli Prosesi (AHP) ve Gri İlişkisel Analiz (GİA) Yöntemiyle Değerlendirilmesi. Muhasebe ve Finansman Dergisi (Ocak), 19-40.

Temizkan, S. P. ve Özhasar, Y. (2020). Eskişehir'deki Seyahat Acentalarının Web Sitelerinin İçerik Analizi. USOBED Uluslararası Batı Karadeniz Sosyal ve Beşerî Bilimler Dergisi, 4(2), 116-129.

TripAdvisor. (2020). Öne çıkın. Tüm Yerlerinizi Doldurun. TripAdvisor. [Online] https://www.tripadvisor.com.tr/business/sponsored-placements [Erişim Tarihi: 12.04.2021].

Turizm Ajansı. (2020). Booking.com Türkiye'ye Geri Dönüyor. Turizm Ajansı. [Online] https://www.turizmajansi.com/haber/booking-com-turkiye-ye-geri-donuyor-h41234 [Erişim Tarihi: 11.04.2021].

Ustasüleyman, T. ve Çelik, P. (2015). AHS ve Bulanık Promethee Yöntemleriyle Destinasyon Seçimini Etkileyen Faktörlerin Önem Derecesinin Belirlenmesi ve En Uygun Destinasyon Seçimi. Uluslararası İktisadi ve İdari İncelemeler Dergisi, 7(14), 85-102.

Uygurtürk, H. ve Korkmaz, T. (2015). Türkiye'deki A Grubu Seyahat Acentalarının Tercih Sıralamasının PROMETHEE Yöntemi ile Belirlenmesi. Business and Economics Research Journal, 6(2), 141-155.

Vignieri, C. (2013). Ranking High on TripAdvisor. 4Hoteliers. [Online] https://www.4hoteliers.com/features/article/7487 [Erişim Tarihi: 12.04.2021].

Yurtlu, M. (2020, 01 06). Türk Otelcilik Sektörüne Yönelik Online Pazarlama Yazllımlarının Mevcut Durumlarının Belirlenmesi: Yazılım Şirketleri Üzerine Nitel Bir Araştırma. Yüksek Lisans Tezi. Hatay, İskenderun: İskenderun Teknik Üniversitesi Sosyal Bilimler Enstitüsü.

Zaman, M., Botti, L. and Thanh, T. V. (2016). Weight of Criteria in Hotel Selection: An Empirical Illustration Based on TripAdvisor Criteria. European Journal of Tourism Research (13), 132-138. 